INTERNATIONAL

FOOD POLICY

RESEARCH

INSTITUTE

IFPRI

IFPRI Discussion Paper 01922

April 2020

\title{
Agrifood market participation, household economies of specialization and diversification \\ Evidence from Vietnam
}

\author{
Hiroyuki Takeshima \\ Manmeet Ajmani \\ Devesh Roy \\ Aniq Fadhillah \\ Yanyan Liu
}

Development Strategy and Governance Division

South Asia Regional Office

Markets, Trade, and Institutions Division 


\section{INTERNATIONAL FOOD POLICY RESEARCH INSTITUTE}

The International Food Policy Research Institute (IFPRI), a CGIAR Research Center established in 1975, provides research-based policy solutions to sustainably reduce poverty and end hunger and malnutrition.

IFPRI's strategic research aims to foster a climate-resilient and sustainable food supply; promote healthy diets and nutrition for all; build inclusive and efficient markets, trade systems, and food industries; transform agricultural and rural economies; and strengthen institutions and governance. Gender is integrated in all the Institute's work. Partnerships, communications, capacity strengthening, and data and knowledge management are essential components to translate IFPRI's research from action to impact. The Institute's regional and country programs play a critical role in responding to demand for food policy research and in delivering holistic support for country-led development. IFPRI collaborates with partners around the world.

\section{AUTHORS}

Hiroyuki Takeshima (H.takeshima@cgiar.org) is a Senior Research Fellow in the Development Strategy and Governance Division of the International Food Policy Research Institute (IFPRI), Washongton, DC.

Manmeet Ajmani (M.Ajmani@cgiar.org) is a Research Analyst in IFPRI's South Asia Regional Office (SAR), New Delhi.

Devesh Roy (D.Roy@cgiar.org) is a Senior Research Fellow in IFPRI's Agriculture for Nutrition and Health (A4NH) Division, SAR office, New Delhi.

Aniq Fadhillah (A.Fadhillah@cgiar.org is the Policy Facilitator for IFPRI's SAR, Jakarta, Indonesia.

Yanyan Liu (Y.Liu@,cgiar.org) is a Senior Research Fellow in IFPRI's Markets, Trade, and Institutions Division, Washington,DC.

\footnotetext{
Notices

${ }^{1}$ IFPRI Discussion Papers contain preliminary material and research results and are circulated in order to stimulate discussion and critical comment. They have not been subject to a formal external review via IFPRI's Publications Review Committee. Any opinions stated herein are those of the author(s) and are not necessarily representative of or endorsed by IFPRI.

${ }^{2}$ The boundaries and names shown and the designations used on the map(s) herein do not imply official endorsement or acceptance by the International Food Policy Research Institute (IFPRI) or its partners and contributors.

${ }^{3}$ Copyright remains with the authors. The authors are free to proceed, without further IFPRI permission, to publish this paper, or any revised version of it, in outlets such as journals, books, and other publications.
} 


\begin{abstract}
Despite the growth of agrifood markets, and gradual structural transformation, smallholders persist in Asia. Such patterns are at odds with the views that market growth should encourage more specialization whereby smallholders' transition to either larger farmers or specialized nonfarm households. Using the panel household data in Vietnam, this study investigates how participation in agrifood markets affect smallholder households' economies of scope (EOS) in diversifying into agriculture and non-agricultural income-earning activities. We find that, greater agrifood market participation proxied by the increased food purchase generally increases EOS between agriculture and non-agricultural activities at the household level. Moreover, it leads to greater labor productivity in agriculture, and also increases female household members' diversifications into both agriculture and non-agricultural income-earning activities. These effects are relatively stronger and more consistent than conventional indicators of agrifood product sales or proximity to the market. The results shed more light on how exactly smallholders in Vietnam persist in the face of agrifood market growth, and what kind of their relations with such a growing market can be promoted in ways that enhance their livelihoods in the short- to medium- terms.
\end{abstract}

Keyword: Agrifood market participation; smallholder; economies of scope; primal model; dual model; Vietnam 


\section{Acknowledgments}

We appreciate the comments and suggestions received from the participants of International Conferences in Phnom Penh, Cambodia in December 2018 and Bangkok, Thailand in 2019, researchers from The Southeast Asian Regional Center for Graduate Study and Research in Agriculture (SEARCA), as well as from Pramod Kumar Joshi and Shahidur Rashid.

We would like to thank the International Fund for Agricultural Development (IFAD), and the CGIAR Research Program on Policies, Institutions, and Markets (PIM), led by the International Food Policy Research Institute (IFPRI) and carried out with support from the CGIAR Trust Fund, for providing financial support to conduct this study. Authors are responsible for the remaining errors. 


\section{Introduction}

Supporting smallholder farm households (SFHs) has been considered central to achieve multiple Sustainable Development Goals (SDGs), including poverty reduction, food security improvements, as well as inclusive growth and rural revitalization, among others (World Bank 2007; ADB 2012; IFPRI 2019). Among the factors and processes that are considered beneficial for SFHs, market developments and greater participation by SFHs, and gradual transition into the non-agricultural sector, are some of the prominent ones (e.g., Lanjouw \& Lanjouw 2001; World Bank 2007; Reardon \& Timmer 2007; Barrett 2008). Knowledge gaps, however, remain regarding the precise linkages between such agrifood market participation and SFHs' expansions into the non-agricultural sector.

This study partly fills this knowledge gap, by empirically investigating how participation in agrifood markets affect SFHs. Specifically, we ask the following questions; do most SFHs specialize (into agriculture, or non-agriculture, respectively), or diversify into both agriculture and non-agriculture? More importantly, how does market participation affect economies of scope (EOS) / economies of diversification into agriculture and non-agricultural activities at the household level? In doing so, we also focus on the role of food purchase, in addition to food sales, by SFHs.

We provide some evidence toward these questions by using 2002-2016 rounds of Vietnamese Household Living Standard Survey (VHLSS) data. We apply empirical methodologies for assessing EOS as well as the effects of various indicators of SFHs' market participation on households' EOS between agriculture and non-agricultural activities.

Vietnam is an important case to assess the aforementioned research questions. The country has recently experienced significant economic growth and structural transformation (Mccaig \& Pavpnik 2016). Its domestic agrifood market and value-chain developments have also been considerable, and the share of purchased food in total food consumption has reached 70 percent in recent years (Reardon 2015). At the same time, the agricultural sector has continued to lag behind other sectors. In the late $2010 \mathrm{~s}, 40 \%$ of the workforce was still employed in the agricultural sector which accounted for only $15 \%$ of the GDP (World Bank 2020). While the employment share had declined from around $50 \%$ in the mid-2000s, integrating SFHs with the rest of the economy has remained a key economic challenge in the country. Therefore, understanding how their greater integrations with emerging agrifood markets contribute to the transformation of SFHs' economic characteristics, has important implications on rural revitalization and inclusive growth in Vietnam.

VHLSS is ideal for investigating aforementioned questions because, as is described below, it provides not only large sample of panel household data, but also provides detailed information on revenues and costs of both agricultural and non-agricultural activities of the households, which are necessary for accurate estimation of the effect of market participation on EOS.

We find that greater agrifood market participation proxied by the increased food purchase generally increases EOS between agriculture and non-agricultural activities at the household level. Moreover, it leads to greater labor productivity in agriculture, and also increases female household members' diversifications into both agriculture and non-agricultural income-earning activities. These effects are relatively stronger and more consistent than conventional indicators of agrifood product sales or proximity to the market.

Our study contributes to various strands of literature. First, the study contributes to the growing literature on agrifood market transformation and SFHs' participation (e.g., Reardon 
2015), by shedding further light on the transformational effects on SFHs' economic characteristics like EOS. By focusing on both food sales and food purchase markets, we also highlight the multi-dimensional aspects of the linkages between the agrifood market and SFHs' transformation.

Second, the issues are also relevant to the literature on the future of SFHs. Despite considerable growth and transformation of food value-chain in Asia and expanding commercialization potentials, SFHs have persisted in many Asian countries (Rigg et al. 2016, 2018). Our study provides some insights on how increased participation in agrifood markets have actually helped SFHs to remain, by inducing more diversification into both agriculture and nonagriculture, rather than specialization, at the household levels, at least in Vietnam in the recent decades. Shedding lights on market-induced household-level economic diversifications also contribute to the literature on farm-nonfarm linkages (Haggblade et al. 1989; Lanjouw \& Lanjouw 2001).

Third, more broadly, the study adds insight into the relations between market exchange and agent's specializations as well as diversifications in economic activities. Growing market exchange in goods and participation therein, either locally or internationally, has been generally considered to be associated with agents' specializations along comparative advantages (e.g., Chavas 2001, p.275; Reardon \& Timmer 2005). In one way, our study offers a counterexample to such conventional wisdom by showing the linkage between market participation and EOS. Relatedly, our study also contributes to the literature on EOS. EOS has conventionally been one of the important characteristics investigated in economic and agricultural economic literature (Baumol et al. 1982; Coelli \& Perelman 1996; Chavas 2001; Coelli \& Fleming 2004; Jin et al. 2005; Nguyen 2017), and our study adds further empirical evidence in the particular case of household-level EOS in agriculture and non-agricultural activities in Vietnam. Similarly, recent literature on EOS has also focused on identifying factors that affect EOS in various contexts (e.g., effects of mechanization on EOS among crops by Takeshima et al. 2020). Our study contributes to this strand of literature by assessing the role of market participation on EOS.

The rest of the paper is structured as follows. Section 2 discusses the testable hypothesis. Section 3 discusses the empirical framework. Section 4 describes the data and variables, as well as descriptive statistics. Section 5 presents and discusses the main results. Finally, section 6 concludes.

\section{Market participation and economies of scope}

For SFHs in developing countries, agrifood market participation can be either through sales, or purchase of food. The transition from semi-subsistence to more sales-oriented farming has been considered an important process of transformation for some SFHs (Barrett 2008). At the same time, many SFHs in many developing countries, including those in Vietnam, are netbuyers of food (Flores-Moya et al. 1978; Weber et al. 1988; Larsson 2005; Barrett 2008; Jayne et al. 2010), and food purchase is one of their important linkages to the market.

For many SFHs, participation in agrifood markets (at either extensive or intensive margins) can affect the EOS in agricultural and non-agricultural activities. For example, participation in the agrifood market generally provides greater opportunities for households to expand into activities in other sectors (non-agricultural activities for farm households, and farm activities for non-farm households). The availability of cheaper food from the market lowers the returns to household agricultural labor at the intensive margin, which then lowers the opportunity costs of these household labor force. This lowers the costs of engaging in certain non-farm 
activities, and EOS arises from such cost advantage of diversifying into non-agricultural activities over a continuous specialization in agricultural activities. Similarly, the availability of more elastic demand in the market for food and agricultural products can also raise returns to farming for households that were not previously engaging in farming. For example, in Africa where food demand has kept rising in the market, urban residents have started investing in farm businesses in recent years, even leading to the relative growth of average farm size in some countries (Jayne et al. 2016).

EOS can also rise because benefits from specialization can remain limited even after greater market participation. Why may these households not specialize in farming or non-farm activities? Risk-aversion can raise the relative costs of specialization as risk-premiums must also be incurred. Insufficient returns-to-scale in farming can be another potential factor. Because most SFHs have insufficient capital, marginal returns to labor in farming may decline quickly below non-farm wages, at which point, non-farm activities bring in higher returns to additional labor used. Also, because farm plots in Asia including Vietnam tend to be not only fragmented but also scattered spatially, marginal returns to aggregating land may be limited at higher margins for many households (e.g., Deininger et al. 2017). At the same time, these SFHs continue some farming because marginal returns to factors (land, labor, etc.) from farming may still start out high (high returns to the first few units of land or labor used in farming). This is potentially because farmer-specific knowledge about their farmland conditions, which they have accumulated over many years of farming on their farms, can be substantial, and not easily transferrable to outsiders. For example, especially for rice, knowledge spill-over potential is relatively low in Asia, partly because growing conditions are still highly heterogeneous across farms (Munshi 2004).

Past studies suggested that EOS may arise or decline from a number of reasons; the above hypotheses also reflect these aspects of EOS. The versatility of production factors across activities is an important condition. For example, where land and labor are versatile between rice and non-rice crop, such as in Vietnam, EOS is found to exist between these crops (Nguyen 2017). EOS for agricultural R\&D institution, from engaging in $R \& D$ on multiple types of crops, is found to arise if certain knowledge on plant breeding and other resources are versatile and applicable for multiple crops (e.g., sharing of administration cost, support staff, experiment fields, and other facilities) (Jin et al. 2005). EOS can decline if, for example, the production season is similar between two crops, and they compete for the same resource at the same time (Coelli \& Flemming 2004). Conversely, if non-agricultural activities are less seasonal, they may not compete with agricultural activities for household labor, and thus keeping EOS high between agriculture and non-agricultural activities. Note that our focus is EOS at the household level. The labor allocation within the households may involve either specialization by individual members into agriculture or non-agricultural activities, or diversification even at individual member levels, i.e., more members engaging in both agriculture and non-agricultural activities. Gender differences in these patterns can also arise if they are associated with intra-household gender differences in access to resources (e.g., farm plots, capital), human capital, among others.

\section{Empirical approach}

Our primary empirical goal is to estimate the effects of household's market participation on their EOS in various aspects. Three estimation issues arise, given the data at hand, which are discussed here. First, EOS can be estimated through both primal and dual approaches (Baumol et al. 1982; Coelli \& Perelman, 1996; Coelli and Fleming, 2004; Irz and Thirtle, 2004; Jin et al. 
2005; Renner et al., 2014; Nguyen, 2017). Second, both short-run (SR) models and long-run (LR) models can be estimated for the Primal model (e.g., Takeshima et al. 2020). The dual model is estimated only for LR, and thus hereafter, LR-models refer to both the LR-Primalmodel and Dual model. Estimating LR-models in addition to SR-models is important also because production characteristics like EOS are sometimes more medium-to-long term, rather than short term, concepts. ${ }^{1}$ Using these various methods allows us to obtain robust results. SRmodels are more in line with standard fixed-effects panel data specification. LR-models are largely equivalent to cross-sectional specifications, except that EOS is estimated more accurately taking advantage of panel data specification using sub-periods within a cross-sectional framework. ${ }^{2}$ Third, different approaches are used for SR- and LR-models in addressing potential endogeneity of market participation variables.

\subsection{Primal models for EOS estimation}

In the primal-model, EOS between two activities can be estimated through the input distance function (IDF) (Coelli and Perelman, 1996, 2000; Coelli and Fleming, 2004; Irz and Thirtle, 2004; Renner et al., 2014; Nguyen, 2017). Specifically, we parameterize the inputdistance $(D)$ as,

$$
\begin{aligned}
\ln D=\alpha_{0}+\sum_{j=1}^{2} \alpha_{j} \ln y_{j}+\sum_{n=1}^{N} \alpha_{j} \ln x_{n}+0.5 \sum_{j=1}^{2} \sum_{k=1}^{2} \alpha_{j k} \ln y_{j} \ln y_{k} \\
+0.5 \sum_{n=1}^{N} \sum_{q=1}^{N} \alpha_{n q} \ln x_{n} \ln x_{q}+\sum_{n=1}^{N} \sum_{j=1}^{2} \alpha_{n j} \ln x_{n} \ln y_{j}+\beta_{Z} \cdot Z
\end{aligned}
$$

which is a function of output of activity $j\left(y_{j}\right)$, values of inputs $n\left(x_{n}\right)$, and other control variables $Z$ that affect $D$ ( $k$ and $q$ are aliases for $j$ and $n$ ). Both $y_{j}$ and $x_{n}$ are measured in monetary values, rather than in physical quantities.

\subsubsection{LR-Primal Model}

Following Coelli \& Perelman (1996), Coelli \& Fleming (2004), Takeshima et al. (2020), parameters in (1) can be estimated by the following regression;

$$
\begin{aligned}
-\ln x_{0, i t}=\alpha_{0} & +\sum_{j=1}^{2} \alpha_{j} \ln y_{j, i t}+\sum_{n=1}^{N} \alpha_{n} \ln x_{n, i t}^{*}+0.5 \sum_{j=1}^{2} \sum_{k=1}^{2} \alpha_{j k} \ln y_{j, i t} \ln y_{k, i t} \\
& +0.5 \sum_{n=1}^{N} \sum_{p=1}^{N} \alpha_{n p} \ln x_{n, i t}^{*} \ln x_{p, i t}^{*}+\sum_{n=1}^{2} \sum_{j=1}^{2} \alpha_{n j} \ln x_{n, i t}^{*} \ln y_{j, i t} \\
& +\beta_{Z} \cdot Z_{i t}+\theta_{i}+v_{i t}-u_{i t}
\end{aligned}
$$

in which $x_{0, i t}$ is labor of the members of household $i$ in year $t$ (a reference input), and $x_{n, i t}^{*}=$ $x_{n, i t} / x_{0, i t}$, where $x_{n, i t}$ are agricultural capital, land, and all the other inputs. $\alpha$ 's, $\beta$ 's and $\theta_{i}$ are

\footnotetext{
${ }^{1}$ This is similar to the understanding that other production characteristics like returns-to-scale also tend to change in medium- to long- term, rather than in short-term (Basu 2008; Takeshima 2017). The literature also often define adoption as a long-run equilibrium rather than short-term fluctuations (Feder et al. 1985), which may be more accurately characterized through the frequency of technology use over time.

${ }^{2}$ Using cross-sectional specifications to analyze long-run phenomena, while using fixed-effects panel-specification to analyze short-run phenomena, is common in the literature (e.g., Squires, 1987; Sheng et al., 2015; Gollin et al., 2016).
} 
estimated parameters. $\theta_{i}$ is unobserved, time-invariant household fixed-effects, while $v_{i t}$ and $u_{i t}$ are stochastic terms with $v_{i t} \sim$ i.i.d. $N\left(0, \sigma_{v}^{2}\right)$ and $u_{i t} \sim$ i.i.d. $\left|N\left(0, \sigma_{u}^{2}\right)\right|$. Equation (1) becomes operationalized in (2) by specifying $v_{i t}-u_{i t}=-\ln D_{i t}$ (Coelli \& Perelman 1996). $v_{i t}$ and $u_{i t}$ are obtained by estimating equation (2) by corrected ordinary least squares (COLS) (Amsler et al. 2016). In the primal-model, $x$ 's are combined inputs used for both activities, and not disaggregated for specific activity. In contrast, Dual-model described below uses information of $x$ 's disaggregated for each activity.

From (2), EOS between two activities are estimated as:

$$
\frac{\partial^{2} D}{\partial y_{1} \partial y_{2}}=\frac{\left(\frac{\partial D}{\partial y_{1}}\right)}{\partial y_{2}}=\frac{\left(\frac{\partial \ln D}{\partial \ln y_{1}} \cdot \frac{D}{y_{1}}\right)}{\partial y_{2}}=\frac{\left(\frac{\partial \ln D}{\partial \ln y_{1}} \cdot \frac{D}{y_{1}}\right)}{\partial \ln y_{2}} \cdot \frac{1}{y_{2}}=\alpha_{j k} \cdot \frac{D}{y_{1} y_{2}}
$$

in which, $\alpha_{j k}>0\left(\alpha_{j k}<0\right)$ indicates EOS (diseconomies of scope) (Coelli \& Fleming 2004; Coelli \& Perelman 1996; Takeshima et al. 2020).

As is described below, in LR-primal-model, we assess the impact of market participation on EOS by estimating (2) and (3) separately among adopters and nonadopters, applying respective weights $w_{i}$ to samples, where $w_{i}$ is the inverse of the estimated probability that the household $i$ 's indicator of market participation exceeds some thresholds (estimation of $w_{i}$, as well as discussions of indicators of market participation, thresholds and robustness of results, are provided in later sections), and then comparing the signs and statistical significance of $\alpha_{j k}$ between the adopters and nonadopters. Since EOS is calculated based on the IPW sample, a simple comparison between two types of households suffices to attribute any differences to market participation.

\subsubsection{SR-Primal Model}

Following Takeshima et al. (2020), SR-primal model can be estimated by (4):

$$
\begin{aligned}
& -\ln x_{0, i t}=\alpha_{0}+\sum_{j=1}^{2} \alpha_{j} \ln y_{j, i t}+\sum_{n=1}^{N} \alpha_{n} \ln x_{n, i t}^{*}+0.5 \sum_{j=1}^{2} \sum_{k=1}^{2} \alpha_{j k} \ln y_{j, i t} \ln y_{k, i t} \\
& +0.5 \sum_{n=1}^{N} \sum_{p=1}^{N} \alpha_{n p} \ln x_{n, i t}^{*} \ln x_{p, i t}^{*}+\sum_{n=1}^{N} \sum_{j=1}^{2} \alpha_{n j} \ln x_{n, i t}^{*} \ln y_{j, i t}+\beta_{Z} \cdot Z_{i t}+\alpha_{0}^{M} M_{i t} \\
& +\sum_{j=1}^{2} \alpha_{j}^{M}\left(\ln y_{j, i t} \cdot M_{i t}\right)+\sum_{n=1}^{N} \alpha_{n}^{M}\left(\ln x_{n, i t}^{*} \cdot M_{i t}\right) \\
& +0.5 \sum_{j=1}^{2} \sum_{k=1}^{2} \alpha_{j k}^{M}\left(\ln y_{j, i t} \ln y_{k, i t} \cdot M_{i t}\right)+0.5 \sum_{n=1}^{N} \sum_{p=1}^{N} \alpha_{n p}^{M}\left(\ln x_{n, i t}^{*} \ln x_{p, i t}^{*} \cdot M_{i t}\right) \\
& +\sum_{n=1}^{N} \sum_{j=1}^{2} \alpha_{n j}^{M}\left(\ln x_{n, i t}^{*} \ln y_{j, i t} \cdot M_{i t}\right)+\beta_{Z}^{M} \cdot Z_{i t} \cdot M_{i t}+\theta_{i}+v_{i t}-u_{i t},
\end{aligned}
$$

in which $M_{i t}$ a function of an indicator of market participation. Parameters $\alpha_{0}^{M}, \alpha_{j}^{M}, \alpha_{n}^{M}, \alpha_{j k}^{M}$, $\alpha_{n p}^{M}, \alpha_{n j}^{M}$ and $\beta_{Z}^{M}$ are counterparts to $\alpha_{0}, \alpha_{j}, \alpha_{n}, \alpha_{j k}, \alpha_{n p}, \alpha_{n j}$ and $\beta_{Z}$, respectively in (3), and capture the differential effects of market participation indicator $M_{i t}$ on respective variable. In the SR-primal-model (4), the signs and statistical significance of the parameter $\alpha_{j k}^{M}(j \neq k)$ are interpreted as the change in EOS caused by the market participation. 
The dual-model follows Baumol et al. (1982), which has been extended to the agricultural literature (e.g., Jin et al. 2005). For the case of two activities, we estimate singleactivity cost functions;

$$
\begin{aligned}
C_{1, i t} & =\gamma_{1}+\delta_{1} y_{1, i t}+\delta_{11} y_{1, i t}^{2}+\delta_{1 Y Z}\left(y_{1, i t} Z_{i t}\right)+\delta_{1 Z} Z_{i t}+\delta_{C 1 i}+\varepsilon_{1, i t} \\
C_{2, i t}=\gamma_{2} & +\delta_{2} y_{2, i t}+\delta_{22} y_{2, i t}^{2}+\delta_{2 Y Z}\left(y_{2, i t} Z_{i t}\right)+\delta_{2 Z} Z_{i t}+\delta_{C 2 i}+\varepsilon_{2, i t},
\end{aligned}
$$

where the cost of activity $j\left(C_{j}\right)(j=1,2)$ is parameterized as a function of output $y_{j}$ and its square $y_{j}^{2}$, and $Z$. Parameters $\gamma, \delta$ 's are estimated parameters, while $\varepsilon$ 's are idiosyncratic errors. $\delta_{\mathrm{C} 1 \mathrm{i}}, \delta_{\mathrm{C} 2 \mathrm{i}}$ are time-invariant household fixed-effects. We also estimate the multiple-activities cost function,

$$
\begin{aligned}
& C_{12, i t}=\Gamma+\Delta_{1} y_{1, i t}+\Delta_{2} y_{2, i t}+\Delta_{12}\left(y_{1, i t} y_{2, i t}\right)+\Delta_{1 Y Z}\left(y_{1, i t} Z_{i t}\right)+ \\
& \Delta_{2 Y Z}\left(y_{2, i t} Z_{i t}\right)+\Delta_{Z} Z_{i t}+\Delta_{C 12 i}+E_{i t},
\end{aligned}
$$

where $C_{12}=C_{1}+C_{2} . \Gamma$ 's and $\Delta$ 's are estimated parameters while $E$ is an idiosyncratic error. $\Delta_{\mathrm{C} 12 \mathrm{i}}$ is time-invariant household fixed-effects.

Following Jin et al. (2005), we calculate sample medians of predicted values of $C_{1}, C_{2}$, and $C_{12}\left(\bar{C}_{1}, \bar{C}_{2}\right.$ and $\bar{C}_{12}$, respectively), and EOS as:

$$
\operatorname{EOS}_{\text {Dual }}=\frac{\bar{C}_{12}-\bar{C}_{1}-\bar{C}_{2}}{\bar{C}_{12}}
$$

$E_{\text {Dual }}<0\left(E_{\text {OOS }}\right.$ Dual $\left.>0\right)$ indicates EOS (diseconomies of scope).

As in the LR-primal-model, dual-models (5) through (7) are estimated separately for adopters and non-adopter samples, using $w_{i}$ as weights. We then compare EOS between the two samples.

\subsection{Addressing endogeneity of market participation in LR models through inverse-probability-weights method}

The estimation of EOS in both Primal and Dual models relies on the standard assumptions in the panel data that inputs ( $x$ 's other than $x_{0, i t}$ ) and outputs $(y$ 's) are exogenous to $x_{0, i t}$ and costs $\left(C\right.$ 's), conditional on time-invariant household fixed-effects $\theta_{i}, \delta_{i}^{C 1}, \delta_{i}^{C 2}$ and $\Delta_{i}^{C 12}$ (Coelli \& Flemming 1996, 2004; Irz \& Thirtle 2004; Jin et al. 2005; Renner et al. 2014).

The potential endogeneity of variable $M$ is a less standard issue. The Primal-SR-models, rely on stronger assumptions that $M_{i t}$ is also exogenous in the respective equation, conditional on time-invariant household fixed effects $\theta_{i}, \delta_{i}^{C 1}, \delta_{i}^{C 2}$ and $\Delta_{i}^{C 12}$. The advantages of this assumption is that the estimation of the effect of $M_{i t}$ on EOS is more straightforward and efficient, requiring only standard panel fixed-effects models (Takeshima et al. 2020).

The LR-model also assumes that $M_{i}$ is exogenous conditional on household fixed-effects. However, as LR-models are essentially cross-sectional models, household fixed-effects cannot be directly estimated. Instead, LR-models use an alternative estimate of household fixed-effects, through IPW-method which involves applying certain weights $w_{i}$ to samples used. Specifically, $w_{i}$ is estimated as follows; we first estimate through a probit regression the probability that the household $i$ 's indicator of market participation exceeds pre-determined thresholds:

$$
\text { Probability }(M=1 \mid V)=\hat{p}=\Phi(V \eta)=\int_{-\infty}^{V \eta} \phi(v) d v .
$$


$M$ is a binary variable, which takes the value of one if market-participation indicator exceeds the threshold and zero otherwise. $V$ is a vector of household characteristics and $\eta$ is a vector of estimated parameters. Estimated probability, $\hat{p}$, is computed through the normal distribution function $\Phi(\cdot)$. Then,

$$
\begin{gathered}
w_{i}=\frac{1}{\hat{p}}(\text { for intensive market participants }) \\
w_{i}=\frac{1}{1-\hat{p}}(\text { for subsistence households }) .
\end{gathered}
$$

which is defined time-invariant over the panel period for each household.

As is described, we apply both SR and LR-models to panel data. In LR-models, following earlier studies (e.g. Takeshima et al. 2020), we define $M=1$ as household's average market-participation indicator exceeding the thresholds over the waves of the panel data. Therefore, in LR-model, $M$ is a constant within a household across all panel periods. $V$ consists of the average values of relevant exogenous variables $Z$ over the waves of the panel, as well as time-invariant exogenous variables including certain agroecological variables that are timeinvariant. This is similar to the classical correlated-random-effects (CRE) model (Mundlak 1978; Chamberlain 1984); in SR-model, $\mathrm{M}$ is considered exogenous conditional on time-invariant unobservable household-fixed effects $\theta_{i}, \delta_{i}^{C 1}, \delta_{i}^{C 2}$ and $\Delta_{i}^{C 12}$. In LR-model, potentially endogeneity of $M$ is addressed by controlling for $w_{i}$ which is one form of CRE.

\subsection{Other empirical issues}

3.4.1 Standard errors

In Dual-models, standard errors are estimated by paired-bootstrap (Efron 1979; Freedman 1981). LR-Primal model is estimated through STATA's teffects ipwra command. In this command, both the probit equation to estimate the weights, and main equations, are estimated jointly through generalized method of moments (GMM) estimators, and standard errors are also obtained as Huber-White-robust sandwich standard errors.

\subsubsection{Sample selection and attrition}

EOS estimation requires information on each economic activity of interest (e.g., farm and non-farm activities for estimation of EOS between these activities). Therefore, households that stop engaging in one of these activities cannot be included in the analyses, leading to attrition / accretion issues. Heckman-type sample selection model has been commonly used in panel models with attritions (Dustmann \& Rochina-Barrachina 2007). However, Heckman type sample selection model has been known to suffer from multicollinearity problems, typically because the correction terms are often functions of linear combinations of the same variables that appear in the main equations (Puhani 2000). Therefore, instead of directly incorporating sample-selection bias correction, we show that the patterns of attritions are fairly neutral, and thus unlikely to bias our main results.

\subsection{Indicators of agrifood market participation}

We proxy the degrees of SFHs' participation in agrifood markets using the following variables: (a) value-shares of food purchased from the market to total food consumed by the household in the previous 12 months period; (b) value-share of agricultural outputs sold to total values of production (all products combined); and (c) proximity to the nearest market. Either (a) or (b) is a common condition that is characterized as so-called "market participation" that is 
distinguished from the opposite regime of so-called "autarky" (e.g., Barrett 2008; Key et al. 2000). SFHs in many developing countries, including those in Vietnam, are net-buyers of food (Flores-Moya et al. 1978; Weber et al. 1988; Larsson 2005; Barrett 2008; Jayne et al. 2010), and food purchase is one of their important linkages to the market. At the same time, many studies focusing on SFHs' market-participation have equally highlighted the importance of market-sales as opposed to subsistence (Goetz 1992; Heltberg \& Tarp 2002; Alene et al. 2008; Ouma et al. 2010). Lastly, the proximity to the market facility has been considered an important precondition for market participation in either purchase or sales, as well as a factor that alleviates isolation (Fafchamps \& Shilpi 2003, 2008).

\section{Data and descriptive results}

\subsection{Data}

Our analyses primarily use the Vietnam Living Standard Surveys (VLSS) data collected in 1998, and the Vietnam Household Living Standards Survey (VHLSS) conducted biennially between 2002 and 2016 (General Statistics Office of Vietnam). Hereafter, we refer to VLSS by VHLSS. The VHLSSs are representative at the provincial, regional and national levels (Liu et al. 2019). The sample sizes vary in each round, and the information from certain modules, such as food consumption, is available only for the sub-samples. A fraction of VHLSS samples are panel households with varying panel lengths, either two-rounds, three-rounds or four-rounds. We use the whole samples (including non-panel samples) for extracting key descriptive statistics and qualitative results, while using exclusively the panel samples for the quantitative analyses.

In addition to VHLSS, we also construct various provincial-level agroclimatic variables from a number of sources. Weather variables, including rainfall and temperature (both historical and concurrent), are from NOAA (2020). Soil data are from FAO et al. (2012). Elevation, topographical data from USGS (1996). Lastly, groundwater table depth is from Fan et al. (2013).

\subsection{Variables}

\subsubsection{Inputs, costs, output variables}

Inputs $x$, costs $C$, and output values $y$ are constructed from VHLSS. These variables are all converted into monetary values, so that they can be easily aggregated or comparable across sub-categories. $x$ and $C$ also include the opportunity costs of the household's own factors (land, labor) imputed from the local market values of these factors. Y also includes the imputed marketvalues of farm products that are consumed at home and not sold.

VHLSS 1998 through 2016 use fairly consistent definitions of categories for $x$ and $C$, and $y$. For $x$ and $C$, sub-categories include inputs that are common for both farming and non-farm activities (energy / fuel, minor repair, maintenance, depreciation of fixed assets, rent of land, workshops, shops, machines and other means of production, water, transport, hired labor costs, loan interests, taxes / fees and charges regarded as taxes, and other costs like postage, travel, advertisement, marketing, purchase of designs, survey for design, production insurance, plant protection fund, field improvement fund, agri-extension fund, administration management fund, feed for ploughing cattle, etc.); farming-specific inputs (agricultural inputs like seeds, fertilizer, chemicals, feed, young animals, medicines for animals, hire of ploughing cattle, inner-field irrigation, etc.); and non-farm enterprise-specific inputs / costs (raw materials, small nondurable tools, costs of treatment of sewage and solid waste). 
For $y$, agriculture products includes crops (rice, non-rice food crops, industrial crops, tree crops), livestock products (live animal, meat and milk, eggs and other animal byproducts like skin/hide), fishery / aquaculture products, forestry products, and crop-by-products (rice straw, leaf and stem, firewood, and other collected products). Similarly for $y$, off-farm revenues include off-farm enterprises revenues, wage earnings, and other miscellaneous incomes (capital gain, remittances, retirement incomes of some household members). Off-farm enterprises also include businesses that still mainly target farming by other households, such as hiring-out of agriculturerelated service (mechanization service, irrigation, pest control, pest prevention, rice threshing, plucking of rice, etc.).

\subsubsection{Control variables $\mathrm{Z}$ and $\mathrm{V}$}

Control variables $Z$ are factors that affect the observed reference inputs use (i.e., $x_{0, i t}$ ) and production costs $C$, aside from the effects through pure economic characteristics of the production system. Inclusion of variables $\mathrm{Z}$ allow us to correctly separate out the changes in and effects of economies of scope, which is our primary interest. Specifically, $Z$ include the following.

Household demographics, such as the number of household members by gender and age groups, average education levels of household head and working-age members, and gender of household heads, potentially captures the unobserved opportunity costs and marginal returns of household labors (e.g., Jacoby 1993, Skoufias 1994), which also affect the relative returns and costs of specialization and diversification, but not fully captured by observed market wages and prices. Following the literature (Takeshima et al. 2020), we use four age-groups; 0 - 5, 6-19, 20 -60 , and above $60 .^{3}$

Observed prices of key agricultural inputs (market wages, fertilizer, rented land) and outputs (rice) capture the spatial variations in the profitability of farming relative to non-farm activities. Hypothetically, lower (higher) agricultural inputs and higher (lower) output prices may induce greater specialization into agriculture (non-agriculture). However, on the other hand, if these conditions hold in mostly non-farm regions, they may induce diversification into agriculture. Output price is proxied by the price of rice, which is the most ubiquitous crop in Vietnam, and thus comparable across space and over time.

The literature on agricultural transformation has also highlighted the role of a stronger land tenure system in inducing households' greater investment into farming (and potentially specialization into agriculture) or exit from agriculture and specialization into the non-farm activities (e.g., Banerjee et al. 2002; de Janvry et al. 2015), although its actual effects can be more complex particularly among lower-income farm households (Ravallion \& Van de Walle 2008). Variables $Z$ therefore also include two variables; share of annual-crop land without landuse certificate due to the absence of or disputes over area measurements or disputes over owners (a proxy for land tenure security), and the share of farmers in the province who engage in land rental or purchase activities (as a proxy of the prevalence of land market).

Distance to the nearest infrastructure and facilities (such as health facility, road, post office, bank) potentially capture the costs of goods, services and transactions that tend to be more intensively associated with non-agricultural activities (such as labor work in industrial factories,

\footnotetext{
${ }^{3}$ Using different age-groups leads to similar results (results are available from author upon requests). At the same time, various age-group and gender are statistically significant, suggesting the importance of accounting for these various age and gender-groups of household members.
} 
exchanges of legal documents through postal services, or large loans), and thus either diversification or specialization into the non-agricultural sector.

The value of household assets owned captures the overall household wealth that affects various behaviors, including liquidity constraints that affect investments in non-farm capitals, or risk-taking behaviors such as taking market risks and relying more on purchased food instead of subsistence food production (e.g., Takeshima 2018). Similarly, whether the commune received hunger elimination and poverty reduction program in the last three years is used to proxy the constraint due to poverty-trap or food-problem (or alleviation thereof), which often induces households to continue engaging in own-food production in a subsistence way (Schultz 1953).

Furthermore, the value of fridge or cooking assets owned capture factors that affect decisions to purchase food which often have different requirements for refrigerated storage or different cooking methods.

Access to ICT and communication tools are proxied by the ownership of mobile phones, and whether the commune of the household has a radio station. These variables may capture access to various information, which can induce market participation by subsistence farmers (e.g., Zanello 2012), or also affect the investments into education (Keefer \& Khemani 2014) which can particularly affect the productivity of non-farm activities that tend to be more knowledge and information-intensive.

Access to the non-farm industry in the local area, which affects the cost of participating in non-farm income-earning activities, is proxied by three variables; whether there are firms/factories/enterprises within the commune, which employ at least ten workers; whether there are firms/factories/enterprises in the community that employ workers from the commune; the number of workers employed in the five largest non-farm firms/enterprises/factors within the commune.

Lastly, the current climate proxied by annual rainfall and temperature in the province is included to account for the effects of weather-related factors on inputs use and production costs, primarily in the agricultural activities. Further, whether the commune had experienced any natural disaster within the 12 months, is included to account for similar disaster-related effects.

\section{Variables $V$ in (8)}

As was described in the previous section, control variables $V$ in probit equation $(8)$ are average values over the panel period of variables $Z$ described above, as well as other timeinvariant variables. Specifically, $V$ includes following agroclimatic variables at the provincelevel that are time-invariant; detailed soil types (drainage, salinity, sodicity, texture, organic contents, alkalinity), elevation, topography (slope, ruggedness, aspects (directions of the slope)), historical rainfall and temperature (30-years leading up to the first interview years), and groundwater table depth. These agroclimatic variables have been particularly relevant for farm economics in developing countries including Southeast Asia (e.g., Bazzi et al. 2016).

\subsection{Descriptive statistics}

Table 1 summarizes the descriptive statistics of control variables. These statistics suggest that households in the sample are generally male-headed, with seven years of education among working-age members. These households are also mostly asset-poor; the median asset values of about 20 million VND, which is approximately 1,000 USD in 2016. Most households are, however, relatively decent access to various institutions, mostly located within a few kilometers to the nearest market or post office, or banks. For median households, distance to the nearest 
road is $0 \mathrm{~km}$. A majority of households are also in the communes with some non-farm firms, factories, enterprises that employ workers from the communes. These patterns confirm the aforementioned descriptions in Vietnam where SFHs have coexisted alongside a structural transformation in the economy.

Table 1 also presents the statistics for the whole samples of multiple rounds of VHLSS (which are repeated cross-section samples), as well as the samples used in our primary analyses, consisting of panel households with 3-rounds or more, that are reporting food expenditure data with which one of our primary market-participation indicators is constructed. These figures suggest that, the panel samples generally consist of households that are similar to the representative households in Vietnam.

Table 1. Table 0219B. Descriptive statistics

\begin{tabular}{|c|c|c|c|c|c|c|}
\hline \multirow[t]{2}{*}{ Variables } & \multicolumn{3}{|c|}{ All sample } & \multicolumn{3}{|c|}{$\begin{array}{c}\text { Three-rounds panel samples with } \\
\text { food expenditure data }\end{array}$} \\
\hline & mean & median & Std.dev & mean & median & Std.dev \\
\hline \multicolumn{7}{|l|}{ Household demographics } \\
\hline Female $>60$ & 0.25 & 0.00 & 0.44 & 0.22 & 0.00 & 0.42 \\
\hline Female $20-60$ & 1.15 & 1.00 & 0.69 & 1.18 & 1.00 & 0.65 \\
\hline Female $6-19$ & 0.57 & 0.00 & 0.80 & 0.60 & 0.00 & 0.84 \\
\hline Female $0-5$ & 0.17 & 0.00 & 0.43 & 0.18 & 0.00 & 0.45 \\
\hline Male $>60$ & 0.17 & 0.00 & 0.38 & 0.16 & 0.00 & 0.37 \\
\hline Male $20-60$ & 1.09 & 1.00 & 0.73 & 1.17 & 1.00 & 0.73 \\
\hline Male 6-19 & 0.60 & 0.00 & 0.80 & 0.65 & 0.00 & 0.82 \\
\hline Male $0-5$ & 0.19 & 0.00 & 0.43 & 0.18 & 0.00 & 0.44 \\
\hline Household head (female $=1)$ & 0.26 & 0.00 & 0.44 & 0.18 & 0.00 & 0.38 \\
\hline Education of head (years) & 6.51 & 5.00 & 4.71 & 5.78 & 5.00 & 4.32 \\
\hline $\begin{array}{l}\text { Education of working-age } \\
\text { members (years) }\end{array}$ & 6.81 & 7.00 & 4.35 & 6.14 & 7.00 & 3.92 \\
\hline Household assets (value) & 43.75 & 21.59 & 104.98 & 33.25 & 18.79 & 104.47 \\
\hline Fridge (value) & 1.17 & 0.00 & 2.52 & 0.82 & 0.00 & 1.72 \\
\hline Cooking equipment (value) & 0.87 & 0.33 & 1.41 & 0.70 & 0.35 & 1.07 \\
\hline Mobile phones (value) & 0.81 & 0.00 & 2.24 & 0.62 & 0.10 & 1.30 \\
\hline $\begin{array}{l}\text { Distance to the extension office } \\
(\mathrm{km})\end{array}$ & 10.09 & 8.00 & 8.81 & 11.21 & 9.00 & 10.49 \\
\hline Farm wage (male, per day) & 0.122 & 0.112 & 0.046 & 0.126 & 0.122 & 0.046 \\
\hline Farm wage (female, ag, per day) & 0.103 & 0.099 & 0.042 & 0.110 & 0.105 & 0.042 \\
\hline Price of fertilizer (value per ton) & 5.56 & 4.82 & 3.10 & 6.31 & 6.17 & 3.06 \\
\hline Land rental value (12 months / ha) & 1.75 & 1.32 & 1.83 & 1.53 & 1.17 & 1.28 \\
\hline Rice price (value per ton) & 7.04 & 6.85 & 1.35 & 6.71 & 6.51 & 1.01 \\
\hline $\begin{array}{l}\text { Firms / factories / enterprises in the } \\
\text { commune }(\text { yes = 1) }\end{array}$ & 0.74 & 1.00 & 0.44 & 0.72 & 1.00 & 0.45 \\
\hline $\begin{array}{l}\text { Firms / factories / enterprises which } \\
\text { employ workers from the commune } \\
(\text { yes = 1) }\end{array}$ & 0.67 & 1.00 & 0.47 & 0.63 & 1.00 & 0.48 \\
\hline $\begin{array}{l}\text { Workers employed in the } 5 \text { largest } \\
\text { firms / factories / enterprises in the } \\
\text { commune (number) }\end{array}$ & 124.93 & 38.00 & 387.15 & 140.17 & 43.50 & 406.99 \\
\hline $\begin{array}{l}\text { Anti-hunger / poverty relief } \\
\text { program in the commune }(\text { yes }=1)\end{array}$ & 0.60 & 1.00 & 0.49 & 0.61 & 1.00 & 0.49 \\
\hline
\end{tabular}




\begin{tabular}{|c|c|c|c|c|c|c|}
\hline \multirow[t]{2}{*}{ Variables } & \multicolumn{3}{|c|}{ All sample } & \multicolumn{3}{|c|}{$\begin{array}{l}\text { Three-rounds panel samples with } \\
\text { food expenditure data }\end{array}$} \\
\hline & mean & median & Std.dev & mean & median & Std.dev \\
\hline $\begin{array}{l}\text { Share of annual crop land that does } \\
\text { not have land-use certificate ( } \% \text { in } \\
\text { the commune) }\end{array}$ & 8.57 & 0.00 & 19.89 & 10.45 & 0.45 & 21.63 \\
\hline $\begin{array}{l}\text { Share of farmers in the province, } \\
\text { spending on land rental or purchase } \\
(1=100 \%)\end{array}$ & 0.06 & 0.04 & 0.06 & 0.07 & 0.05 & 0.06 \\
\hline Commune radio station (yes $=1$ ) & 0.88 & 1.00 & 0.33 & 0.81 & 1.00 & 0.39 \\
\hline Internet annual subscription (value) & 0.15 & 0.00 & 0.65 & 0.05 & 0.00 & 0.29 \\
\hline Distance to road $(\mathrm{km})$ & 0.44 & 0.00 & 3.04 & 0.46 & 0.00 & 3.18 \\
\hline Distance to market $(\mathrm{km})$ & 1.77 & 0.50 & 4.12 & 2.78 & 1.00 & 5.44 \\
\hline Distance to post office $(\mathrm{km})$ & 2.38 & 1.00 & 4.43 & 3.02 & 2.00 & 5.25 \\
\hline Distance to bank $(\mathrm{km})$ & 6.47 & 5.00 & 7.50 & 8.16 & 5.00 & 9.32 \\
\hline Distance to health facility $(\mathrm{km})$ & 10.97 & 8.67 & 9.60 & 13.64 & 10.75 & 11.61 \\
\hline $\begin{array}{l}\text { Rain (12 month, current in the } \\
\text { survey year, millimeter) }\end{array}$ & 1746.8 & 1678.9 & 401.8 & 1684.8 & 1654.2 & 352.3 \\
\hline $\begin{array}{l}\text { Temperature ( } 12 \text { month average, } \\
\left.\text { current in the survey year, }{ }^{\circ} \mathrm{C}\right)\end{array}$ & 29.9 & 29.3 & 2.6 & 29.2 & 28.8 & 2.7 \\
\hline $\begin{array}{l}\text { Whether the commune had disasters } \\
\text { in the last } 12 \text { months (yes }=1 \text { ) }\end{array}$ & 0.65 & 1.00 & 0.48 & 0.65 & 1.00 & 0.48 \\
\hline Year $=1998$ & 0.04 & & & 0.00 & & \\
\hline Year $=2002$ & 0.06 & & & 0.12 & & \\
\hline Year $=2004$ & 0.16 & & & 0.13 & & \\
\hline Year $=2006$ & 0.24 & & & 0.13 & & \\
\hline Year $=2008$ & 0.15 & & & 0.03 & & \\
\hline Year $=2010$ & 0.09 & & & 0.10 & & \\
\hline Year $=2012$ & 0.08 & & & 0.20 & & \\
\hline Year $=2014$ & 0.07 & & & 0.21 & & \\
\hline Year $=2016$ & 0.10 & & & 0.10 & & \\
\hline Sample size & 111,771 & & & 10,864 & & \\
\hline
\end{tabular}

Source: Authors.

All monetary values are in million 2016 VND. Exchange rate in 2016 was around 1 USD = 21,000 VND.

Table 2 summarizes the reported revenues and production costs of agricultural activities, and the non-agricultural activities of sample households. On average, the sample households have reported overall household revenues in the order of 100 million 2016 VND (approximately USD 5,000) annually. The majority of household revenue is derived from non-farm activities. The production cost figures are somewhat larger than the revenues, possibly due to underreporting of revenues, which is common in household surveys. However, if the reporting errors idiosyncratic, our analyses are still valid and consistent. 
Table 2. Table 0316A Descriptive statistics - revenues, production costs (million 2016 VND)

\begin{tabular}{|c|c|c|c|c|c|c|}
\hline \multirow[t]{2}{*}{ Variables } & \multicolumn{3}{|c|}{ All sample } & \multicolumn{3}{|c|}{$\begin{array}{c}\text { Three-rounds panel samples with } \\
\text { food expenditure data }\end{array}$} \\
\hline & mean & median & Std.dev & mean & median & Std.dev \\
\hline \multicolumn{7}{|l|}{ Revenue (value) } \\
\hline Total & 166.4 & 88.9 & 676.4 & 133.2 & 86.4 & 215.9 \\
\hline Farming & 44.3 & 11.4 & 179.7 & 71.8 & 38.0 & 172.4 \\
\hline Rice & 14.7 & 0.0 & 56.6 & 21.7 & 10.3 & 53.1 \\
\hline Non-rice & 29.6 & 3.2 & 169.5 & 50.1 & 20.0 & 164.8 \\
\hline NF household enterprise & 71.9 & 0.0 & 649.6 & 26.8 & 0.0 & 112.7 \\
\hline NF all & 122.1 & 47.7 & 654.6 & 61.4 & 32.3 & 119.2 \\
\hline \multicolumn{7}{|l|}{ Production costs / inputs } \\
\hline Total (value) & 195.1 & 131.6 & 655.6 & 186.6 & 145.2 & 198.1 \\
\hline Farming (value) & 65.8 & 30.9 & 144.3 & 113.9 & 82.8 & 154.8 \\
\hline Capital (value) & 3.0 & 0.1 & 24.3 & 2.2 & 0.5 & 8.5 \\
\hline Land (ha) & 0.51 & 0.14 & 1.87 & 0.82 & 0.36 & 1.62 \\
\hline \multicolumn{7}{|l|}{ Household labor (person-day) } \\
\hline Adult male & 169.8 & 0.0 & 320.0 & 330.5 & 200.0 & 438.8 \\
\hline Adult female & 193.3 & 40.0 & 335.3 & 385.2 & 265.0 & 440.5 \\
\hline Children & 42.8 & 0.0 & 202.3 & 89.9 & 0.0 & 318.7 \\
\hline Other inputs (value) & 20.7 & 5.3 & 115.1 & 32.4 & 12.8 & 118.6 \\
\hline NF household enterprise (value) & 84.2 & 0.0 & 643.4 & 37.6 & 0.0 & 113.5 \\
\hline Capital (NF) (value) & 2.2 & 0.0 & 23.9 & 0.9 & 0.0 & 5.9 \\
\hline \multicolumn{7}{|l|}{ Household labor (person-day) } \\
\hline Adult male & 105.0 & 0.0 & 281.5 & 75.4 & 0.0 & 243.8 \\
\hline Adult female & 153.1 & 0.0 & 338.9 & 111.6 & 0.0 & 295.9 \\
\hline Children & 10.9 & 0.0 & 99.8 & 10.5 & 0.0 & 100.9 \\
\hline Other inputs (NF) (value) & 49.7 & 0.0 & 627.8 & 13.2 & 0.0 & 86.0 \\
\hline NF all & 129.3 & 62.5 & 645.5 & 72.8 & 36.0 & 126.6 \\
\hline Capital (NF) (value) & 2.2 & 0.0 & 23.9 & 0.9 & 0.0 & 5.9 \\
\hline \multicolumn{7}{|l|}{ Household labor (person-day) } \\
\hline Adult male & 319.1 & 0.0 & 440.9 & 268.8 & 0.0 & 414.7 \\
\hline Adult female & 299.1 & 0.0 & 445.0 & 214.1 & 0.0 & 380.6 \\
\hline Children & 35.9 & 0.0 & 175.9 & 39.9 & 0.0 & 199.3 \\
\hline Other inputs (NF) (value) & 49.7 & 0.0 & 627.8 & 13.2 & 0.0 & 86.0 \\
\hline Sample size & 111,771 & & & 10,864 & & \\
\hline
\end{tabular}

Source: Authors. NF = non-farm. All monetary values are in million 2016 VND.

Table 3 summarizes the two market-participation indicators, other than the distance to the nearest market. For typical households, market-purchased food has accounted for about 70-80\% of the total value of food consumed by the households. Similarly, agrifood commodities sold in the market have accounted for about 60 percent of the imputed value of all agricultural production. 
Table 3. Market participation indicators

\begin{tabular}{|c|c|c|c|c|c|c|c|c|}
\hline \multirow[t]{2}{*}{ Variables } & \multicolumn{4}{|c|}{ All sample with food expenditure data } & \multicolumn{4}{|c|}{$\begin{array}{l}\text { Three-rounds panel samples with food } \\
\text { expenditure data }\end{array}$} \\
\hline & $\begin{array}{l}\text { Sample } \\
\text { size }\end{array}$ & mean & median & Std.dev & $\begin{array}{l}\text { Sample } \\
\text { size }\end{array}$ & mean & median & Std.dev \\
\hline $\begin{array}{l}\text { Value share of market- } \\
\text { purchased food to total } \\
\text { food consumed at home }\end{array}$ & 67,359 & 0.77 & 0.86 & 0.24 & 10,864 & 0.68 & 0.70 & 0.23 \\
\hline $\begin{array}{l}\text { Value share of agrifood } \\
\text { commodities sold, to total } \\
\text { production value (among } \\
\text { food-growing } \\
\text { households) }\end{array}$ & 43,011 & 0.56 & 0.62 & 0.31 & 10,864 & 0.59 & 0.62 & 0.30 \\
\hline
\end{tabular}

Source: Authors.

\subsection{Descriptive analyses}

Figure 1 through Figure 8 illustrate some of the key trends of agrifood market participation and SFHs characteristics, which also motivate our investigation of EOS. Key trends are the following. Over time, the shares of households in Vietnam growing food commodities have declined, in both Northern regions and Southern regions, consistent with the aforementioned narratives of structural transformation in Vietnam in recent years (Figure 1). Importantly, however, the share of households selling food commodities has also declined, which is somewhat contradictory to the growing agrifood market in the country. This does not mean, however, farm households are increasingly becoming subsistence. When viewed in terms of values, the share of agrifood products sold in the market to total production values has been rising (Figure 2). More importantly, Vietnamese households, including agricultural households, have experienced increased shares of purchased-food items to total food consumption, indicating that their primary interactions with growing agrifood markets have been observed through food purchase (Figure 3). These patterns have also been observed in terms of the share of eating-out food to total food consumed (Figure 4). During this time (between 2002 and 2016), the agricultural households have increasingly diversified into non-agricultural income-earning activities, with growing shares of revenues originating from activities other than food production (Figure 5). Similarly, an increasing share of household member's labor is engaged in the nonfarm sector, including non-farm household enterprises and non-farm wage-earning activities (Figure 6). Importantly, these trends are particularly sharper for female members of the household. The share of labor-days in non-farm wage-earning activities accounted for the female members has increased steadily over time, as the share of purchased food to total food consumption has increased (Figure 7). While household members typically specialize in incomeearning activities in one sector, the increasing agrifood market-participation proxied by the share of purchased food to total food consumed, has also been associated with an increasing number of female household members engaging in both agriculture and non-agricultural activities.

\section{Empirical results}

\subsection{Probit regression and balancing property of IPW sample}

Table 4 summarizes the statistics showing the balancing properties of the raw sample and IPW sample. Specifically, it shows the percentage of variables whose means differ significantly between two groups (at significance levels of 10, 5 and 1 percent), defined by various threshold levels (at 25, 50 and 75 percent, respectively) of market participation indicators. For example, 
among raw samples, typically more than half of the variables are statistically significantly different between groups, suggesting low balancing properties. In contrast, among the IPW sample, the percentage of variables with significantly different means are mostly below the corresponding significance levels, which would hold under the null hypothesis of balanced samples. Table 4 thus ensures that any significant differences in EOS below and above thresholds in the IPW sample can be attributed to the level of market participation.

Table 4. Balancing property of raw sample and IPW-adjusted sample (\% of variables with statistically significant difference)

\begin{tabular}{|c|c|c|c|c|c|c|c|}
\hline Models & & \multicolumn{3}{|c|}{ Raw sample } & \multicolumn{3}{|c|}{ IPW sample } \\
\hline & Thresholds & $10 \%$ & $5 \%$ & $1 \%$ & $10 \%$ & $5 \%$ & $1 \%$ \\
\hline \multicolumn{8}{|l|}{ Ag-Non-Ag Activities (all) } \\
\hline \multicolumn{8}{|l|}{ LR-Primal } \\
\hline \multirow[t]{3}{*}{ Value share of purchased food } & $25 \%$ & 68 & 63 & 60 & 3 & 1 & 0 \\
\hline & $50 \%$ & 75 & 70 & 62 & 4 & 1 & 0 \\
\hline & $75 \%$ & 59 & 53 & 44 & 0 & 0 & 0 \\
\hline \multirow{3}{*}{$\begin{array}{l}\text { Value share of agricultural outputs } \\
\text { sold }\end{array}$} & $25 \%$ & 59 & 58 & 49 & 7 & 3 & 1 \\
\hline & $50 \%$ & 73 & 70 & 66 & 12 & 7 & 1 \\
\hline & $75 \%$ & 67 & 63 & 55 & 3 & 1 & 0 \\
\hline \multirow[t]{3}{*}{ Distance to market } & $25 \%$ & 56 & 53 & 41 & 5 & 3 & 2 \\
\hline & $50 \%$ & 52 & 48 & 32 & 4 & 3 & 0 \\
\hline & $75 \%$ & 48 & 40 & 30 & 4 & 2 & 0 \\
\hline \multicolumn{8}{|l|}{ Ag-Non-Ag Enterprises } \\
\hline \multicolumn{8}{|l|}{ LR-Primal } \\
\hline \multirow[t]{3}{*}{ Value share of purchased food } & $25 \%$ & 66 & 62 & 60 & 4 & 1 & 0 \\
\hline & $50 \%$ & 74 & 68 & 60 & 5 & 3 & 1 \\
\hline & $75 \%$ & 62 & 58 & 47 & 0 & 0 & 0 \\
\hline \multirow{3}{*}{$\begin{array}{l}\text { Value share of agricultural outputs } \\
\text { sold }\end{array}$} & $25 \%$ & 58 & 53 & 47 & 4 & 2 & 1 \\
\hline & $50 \%$ & 70 & 68 & 66 & 12 & 1 & 0 \\
\hline & $75 \%$ & 70 & 64 & 55 & 3 & 1 & 0 \\
\hline \multirow[t]{3}{*}{ Distance to market } & $25 \%$ & 58 & 49 & 41 & 7 & 5 & 1 \\
\hline & $50 \%$ & 47 & 38 & 27 & 2 & 1 & 0 \\
\hline & $75 \%$ & 44 & 38 & 27 & 5 & 2 & 1 \\
\hline
\end{tabular}

Source: Authors.

\subsection{Main results}

\subsubsection{Results on EOS}

Table 5 through Table 7 and Table 8 summarize estimated EOS and their differences between samples below and above various thresholds of market participation indicators. Note that, while in primal models, positive signs indicate that more intensive market participation increases EOS, in dual models, they are indicated by the negative signs.

The three market participation indicators generally have positive effects on EOS between agriculture and non-agricultural activities of the household. These results hold between primal and dual models, and whether we focus on SR or LR. In Primal-models, the positive effects on EOS are expressed by the enhanced complementarity between two sectors, and thus higher technical efficiency. In Dual models, the positive effects on EOS are expressed by the reduced cost of joint production in both agriculture and non-agricultural sectors, relative to the cost of 
specialized production in either sector. These generally hold whether we limit the nonagricultural activities to household enterprise, or expand to non-farm wage-earning activities. The EOS within the agricultural sector, particularly EOS between rice and non-rice commodities, is also generally increased by greater market participation indicators. While estimated effects on EOS are sometimes statistically insignificant, no results are statistically significant in supporting the alternative hypothesis (that market participation decreases EOS).

The effects are slightly clearer and sharper for one of the indicators; share of purchased food. The results for the other two indicators (share of sales, and proximity to market) are somewhat weaker. These may reflect that the actual level of market participants may be more accurately captured by the actual purchase of food from the market, while proximity to market is rather a necessary condition instead of sufficient condition for greater market participation. Similarly, greater purchase of food from the market may also reflect closer linkages with the agrifood market because, as was mentioned above, most SFHs in developing countries are net food buyers, while the sales of agricultural commodities may sometimes be concentrated among the relatively small number of large farmers.

Table 5. LR-Primal model results

\begin{tabular}{|c|c|c|c|c|c|c|c|c|}
\hline \multirow{3}{*}{$\begin{array}{l}\text { Market } \\
\text { participation } \\
\text { indicators }\end{array}$} & \multirow[b]{3}{*}{ Threshold } & \multirow[b]{3}{*}{ Samples } & \multicolumn{6}{|c|}{$\begin{array}{c}\text { Sector of household income earning activities for which EOS, and } \\
\text { effect of market participation is estimated }\end{array}$} \\
\hline & & & \multicolumn{2}{|c|}{$\begin{array}{l}\text { Agriculture vs. all } \\
\text { non-agricultural } \\
\text { activities }\end{array}$} & \multicolumn{2}{|c|}{$\begin{array}{l}\text { Agriculture vs. non- } \\
\text { agricultural } \\
\text { enterprises of the } \\
\text { household }\end{array}$} & \multicolumn{2}{|c|}{ Within agriculture } \\
\hline & & & coef & std & coef & std & coef & std \\
\hline \multirow{9}{*}{$\begin{array}{l}\text { Value share of } \\
\text { market- } \\
\text { purchased } \\
\text { food to total } \\
\text { food consumed } \\
\text { at home }\end{array}$} & $25 \%$ & $\overline{\mathrm{A}}$ & $.021 * * *$ & $(.005)$ & $.008 *$ & $(.004)$ & $.017 * *$ & $(.007)$ \\
\hline & $25 \%$ & $\mathrm{~B}$ & .005 & $(.007)$ & -.002 & $(.007)$ & .017 & $(.013)$ \\
\hline & $25 \%$ & Differences & $.015^{*}$ & $(.008)$ & .010 & $(.008)$ & .000 & $(.015)$ \\
\hline & $50 \%$ & $\mathrm{~A}$ & $.023 * * *$ & $(.004)$ & $.020 * * *$ & $(.003)$ & $.023 * * *$ & $(.007)$ \\
\hline & $50 \%$ & $\mathrm{~B}$ & $.015 * *$ & $(.006)$ & .002 & $(.006)$ & $.017 * *$ & $(.008)$ \\
\hline & $50 \%$ & Differences & .008 & $(.007)$ & $.018 * * *$ & $(.007)$ & .007 & $(.011)$ \\
\hline & $75 \%$ & $\mathrm{~A}$ & $.019 * * *$ & $(.006)$ & $.016^{* * *}$ & $(.005)$ & $.023 * * *$ & $(.008)$ \\
\hline & $75 \%$ & $\mathrm{~B}$ & $.025 * * *$ & $(.004)$ & $.014 * * *$ & $(.004)$ & .002 & $(.006)$ \\
\hline & $75 \%$ & Differences & -.006 & $(.007)$ & .002 & $(.006)$ & $.021 * *$ & $(.010)$ \\
\hline \multirow{9}{*}{$\begin{array}{l}\text { Value share of } \\
\text { agrifood } \\
\text { commodities } \\
\text { sold, to total } \\
\text { production } \\
\text { value }\end{array}$} & $25 \%$ & $\mathrm{~A}$ & $.041 * * *$ & $(.003)$ & $.023 * * *$ & $(.003)$ & $.023 * * *$ & $(.006)$ \\
\hline & $25 \%$ & $\mathrm{~B}$ & $.039 * * *$ & $(.008)$ & $.013 *$ & $(.008)$ & $-.025 * *$ & $(.011)$ \\
\hline & $25 \%$ & Differences & .002 & $(.008)$ & .010 & $(.008)$ & $.048 * * *$ & $(.013)$ \\
\hline & $50 \%$ & $\mathrm{~A}$ & $.029 * * *$ & $(.004)$ & $.016 * * *$ & $(.004)$ & $.028 * * *$ & $(.006)$ \\
\hline & $50 \%$ & $\mathrm{~B}$ & $.036^{* * *}$ & $(.005)$ & $.011 * *$ & $(.006)$ & $-.023 * *$ & $(.010)$ \\
\hline & $50 \%$ & Differences & -.008 & $(.006)$ & .005 & $(.007)$ & $.051 * * *$ & $(.012)$ \\
\hline & $75 \%$ & $\mathrm{~A}$ & $.051 * * *$ & $(.005)$ & $.030 * * *$ & $(.005)$ & $.029 * * *$ & $(.007)$ \\
\hline & $75 \%$ & $\mathrm{~B}$ & $.039 * * *$ & $(.005)$ & $.018 * * *$ & $(.004)$ & $-.014 *$ & $(.008)$ \\
\hline & $75 \%$ & Differences & $.011 *$ & $(.007)$ & .012 & $(.007)$ & $.043 * * *$ & $(.010)$ \\
\hline \multirow{9}{*}{$\begin{array}{l}\text { Proximity to } \\
\text { market }\end{array}$} & $25 \%$ & $\mathrm{~A}$ & $.037 * * *$ & $(.006)$ & $.022 * * *$ & $(.005)$ & $.027 * * *$ & $(.010)$ \\
\hline & $25 \%$ & $\mathrm{~B}$ & .012 & $(.008)$ & .010 & $(.007)$ & $.042 * * *$ & $(.012)$ \\
\hline & $25 \%$ & Differences & $.025 * *$ & $(.010)$ & .012 & $(.009)$ & -.015 & $(.016)$ \\
\hline & $50 \%$ & $\mathrm{~A}$ & $.030 * * *$ & $(.004)$ & $.023 * * *$ & $(.003)$ & $.022 * * *$ & $(.007)$ \\
\hline & $50 \%$ & $\mathrm{~B}$ & $.021 * * *$ & $(.007)$ & $.019 * * *$ & $(.007)$ & .011 & $(.009)$ \\
\hline & $50 \%$ & Differences & .009 & $(.008)$ & .004 & $(.008)$ & .011 & $(.011)$ \\
\hline & $75 \%$ & $\mathrm{~A}$ & $.032 * * *$ & $(.006)$ & $.026 * * *$ & $(.005)$ & $.043 * * *$ & $(.008)$ \\
\hline & $75 \%$ & $\mathrm{~B}$ & $.027 * * *$ & $(.005)$ & $.022 * * *$ & $(.004)$ & $.014 *$ & $(.008)$ \\
\hline & $75 \%$ & Differences & .004 & $(.008)$ & .005 & $(.006)$ & $.029 * * *$ & $(.011)$ \\
\hline Sample size & & & 10,864 & & 10,864 & & 10,864 & \\
\hline
\end{tabular}


Table 6. SR-Primal model results

\begin{tabular}{|l|c|c|c|}
\hline \multirow{1}{*}{ Market participation indicators } & \multicolumn{2}{|c|}{$\begin{array}{c}\text { Sector of household income earning activities for which EOS, and } \\
\text { effect of market participation is estimated }\end{array}$} \\
\cline { 2 - 4 } & $\begin{array}{c}\text { Agriculture vs. all } \\
\text { non-agricultural } \\
\text { activities }\end{array}$ & $\begin{array}{c}\text { Agriculture vs. non- } \\
\text { agricultural } \\
\text { enterprises of the } \\
\text { household }\end{array}$ & Within agriculture \\
\hline $\begin{array}{l}\text { Value share of market-purchased } \\
\text { food to total food consumed at home }\end{array}$ & $.038^{* *}(.016)$ & $.016^{*}(.009)$ & $.035^{*}(.021)$ \\
\hline Food sales (lagged) & $-.007(.020)$ & $-.013(.010)$ & $.071^{* * *}(.019)$ \\
\hline Proximity to market (lagged) & $.046^{*}(.028)$ & $.013(.023)$ & $-.023^{* *}(.010)$ \\
\hline Sample size & 10,864 & 10,864 & 10,864 \\
\hline Source: Authors. Asterisks indicate the statistical significance: & $* * * 1 \% \quad * * 5 \%$ & $* 10 \%$ \\
\hline
\end{tabular}

Table 7. Dual model results

\begin{tabular}{|c|c|c|c|c|c|c|c|c|}
\hline \multirow{3}{*}{$\begin{array}{l}\text { Market } \\
\text { participation } \\
\text { indicators } \\
\end{array}$} & \multirow[b]{3}{*}{ Threshold } & \multirow[b]{3}{*}{ Samples } & \multicolumn{6}{|c|}{$\begin{array}{c}\text { Sector of household income earning activities for which EOS, and } \\
\text { effect of market participation is estimated }\end{array}$} \\
\hline & & & \multicolumn{2}{|c|}{$\begin{array}{c}\text { Agriculture vs. all } \\
\text { non-agricultural } \\
\text { activities }\end{array}$} & \multicolumn{2}{|c|}{$\begin{array}{l}\text { Agriculture vs. non- } \\
\text { agricultural } \\
\text { enterprises of the } \\
\text { household }\end{array}$} & \multicolumn{2}{|c|}{ Within agriculture } \\
\hline & & & coef & std & coef & std & coef & std \\
\hline \multirow{9}{*}{$\begin{array}{l}\text { Value share of } \\
\text { market- } \\
\text { purchased } \\
\text { food to total } \\
\text { food consumed } \\
\text { at home }\end{array}$} & $25 \%$ & $\mathrm{~A}$ & $-.278 * * *$ & $(.031)$ & $-1.019 * *$ & $(.454)$ & .311 & $(.221)$ \\
\hline & $25 \%$ & $\mathrm{~B}$ & -.116 & $(.081)$ & -.319 & $(.200)$ & .425 & $(.307)$ \\
\hline & $25 \%$ & Differences & $-.163 *$ & $(.087)$ & -.700 & $(.496)$ & -.114 & $(.378)$ \\
\hline & $50 \%$ & $\mathrm{~A}$ & $-.372 * * *$ & $(.022)$ & $-.689 * * *$ & $(.041)$ & .027 & $(.042)$ \\
\hline & $50 \%$ & $\mathrm{~B}$ & $-.224 * * *$ & $(.009)$ & $-.377 * * *$ & $(.014)$ & $.104 * * *$ & $(.009)$ \\
\hline & $50 \%$ & Differences & $-.148 * * *$ & $(.024)$ & $-.312 * * *$ & (.043) & $-.077 *$ & (.043) \\
\hline & $75 \%$ & $\mathrm{~A}$ & $-.379 * * *$ & $(.046)$ & $-.643 * * *$ & $(.048)$ & .138 & $(.089)$ \\
\hline & $75 \%$ & $\mathrm{~B}$ & $-.277 * * *$ & $(.010)$ & $-.481 * * *$ & $(.018)$ & $.083 * * *$ & $(.008)$ \\
\hline & $75 \%$ & Differences & $-.102 * *$ & $(.047)$ & $-.162 * * *$ & $(.051)$ & .056 & $(.089)$ \\
\hline \multirow{9}{*}{$\begin{array}{l}\text { Value share of } \\
\text { agrifood } \\
\text { commodities } \\
\text { sold, to total } \\
\text { production } \\
\text { value }\end{array}$} & $25 \%$ & $\mathrm{~A}$ & -.018 & $(.212)$ & $-.818 * * *$ & $(.036)$ & $.077 * * *$ & $(.006)$ \\
\hline & $25 \%$ & $\mathrm{~B}$ & -.050 & $(.165)$ & $-.570 * * *$ & $(.014)$ & $.192 * * *$ & $(.014)$ \\
\hline & $25 \%$ & Differences & .033 & $(.269)$ & $-.248 * * *$ & $(.039)$ & $-.116 * * *$ & $(.015)$ \\
\hline & $50 \%$ & $\mathrm{~A}$ & $-.224 * * *$ & $(.012)$ & $-.377 * * *$ & $(.022)$ & $.120 * * *$ & $(.008)$ \\
\hline & $50 \%$ & $\mathrm{~B}$ & $-.242 * * *$ & $(.017)$ & $-.296 * * *$ & $(.012)$ & $.160 * * *$ & $(.008)$ \\
\hline & $50 \%$ & Differences & .017 & $(.020)$ & $-.081 * * *$ & $(.025)$ & $-.041 * * *$ & $(.012)$ \\
\hline & $75 \%$ & $\mathrm{~A}$ & $-.196 * * *$ & $(.022)$ & $-.345 * * *$ & $(.031)$ & $.168 * * *$ & $(.007)$ \\
\hline & $75 \%$ & $\mathrm{~B}$ & $-.192 * * *$ & $(.009)$ & $-.361 * * *$ & $(.014)$ & $.438 * * *$ & $(.024)$ \\
\hline & $75 \%$ & Differences & -.004 & $(.024)$ & .015 & $(.034)$ & $-.270 * * *$ & $(.025)$ \\
\hline \multirow{9}{*}{$\begin{array}{l}\text { Proximity to } \\
\text { market }\end{array}$} & $25 \%$ & $\mathrm{~A}$ & $-.435 * * *$ & $(.013)$ & $-.566 * * *$ & $(.019)$ & $.055 * * *$ & $(.021)$ \\
\hline & $25 \%$ & $\mathrm{~B}$ & $-.323 * * *$ & $(.023)$ & $-.340 * * *$ & $(.025)$ & $.061 * * *$ & $(.014)$ \\
\hline & $25 \%$ & Differences & $-.112 * * *$ & $(.026)$ & $-.226 * * *$ & $(.031)$ & -.006 & $(.025)$ \\
\hline & $50 \%$ & $\mathrm{~A}$ & $-.454 * * *$ & $(.017)$ & $-.685 * * *$ & $(.023)$ & $.227 *$ & $(.126)$ \\
\hline & $50 \%$ & $\mathrm{~B}$ & $-.363 * * *$ & $(.014)$ & $-.595 * * *$ & $(.021)$ & $.198^{*}$ & $(.121)$ \\
\hline & $50 \%$ & Differences & $-.092 * * *$ & $(.022)$ & $-.090 * * *$ & $(.031)$ & .029 & (.175) \\
\hline & $75 \%$ & $\mathrm{~A}$ & -.378 & $(.017)$ & $-.756 * * *$ & $(.072)$ & $.078 * * *$ & $(.020)$ \\
\hline & $75 \%$ & $\mathrm{~B}$ & -.387 & $(.021)$ & $-.757 * * *$ & $(.111)$ & $.087 * * *$ & $(.008)$ \\
\hline & $75 \%$ & Differences & .009 & $(.027)$ & .001 & $(.132)$ & -.009 & $(.022)$ \\
\hline Sample size & & & 10,864 & & 10,864 & & 10,864 & \\
\hline
\end{tabular}


Table 8 summarizes how these market participation indicators are associated with various key agricultural and labor outcomes of the households. Generally, following patterns are observed.

Greater participation in agrifood markets through food purchase is positively associated with overall agricultural labor productivity, particularly in Northern Vietnam (effects in Southern Vietnam are positive but statistically insignificant). Greater food purchases from the market also affect female labor force participation. In particular, it is associated with a greater share of female working-age household members in the household, who diversify in both agriculture and non-agricultural activities, rather than specializing in one sector of occupation. These effects are not observed for male household members. This suggests the potentially added effects of household market participation in the female workforce's economic diversification.

The effects of other agrifood market participation indicators are somewhat weaker, including the share of food sales, and the proximity to the market. These results suggest that, increased food purchase from the market may be a potentially important way for SFHs to benefit from agrifood market growth in Vietnam, in addition to conventional pathways like the sales of agrifood commodities or enhanced proximity to the nearest market alone.

Table 8. Effects of market participations on other main outcomes - effects of one-standard deviation change in market participation indicators on standard deviation change in outcomes

\begin{tabular}{|c|c|c|c|c|c|c|c|}
\hline \multirow{3}{*}{$\begin{array}{l}\text { Market participation } \\
\text { indicators }\end{array}$} & \multicolumn{7}{|c|}{ Outcomes } \\
\hline & \multirow{2}{*}{$\begin{array}{l}\text { Rice } \\
\text { productio } \\
\text { n value } \\
\text { per rice } \\
\text { area }\end{array}$} & \multirow[t]{2}{*}{$\begin{array}{l}\text { Crop } \\
\text { productio } \\
\text { n per area }\end{array}$} & \multicolumn{3}{|c|}{$\begin{array}{l}\text { Overall ag labor productivity } \\
\text { (profit per ag labor) }\end{array}$} & \multicolumn{2}{|c|}{$\begin{array}{l}\text { Household-level labor } \\
\text { specialization or } \\
\text { diversification - }\end{array}$} \\
\hline & & & Country & North & South & Female & Male \\
\hline $\begin{array}{l}\text { Value share of market- } \\
\text { purchased food to total } \\
\text { food consumed at home }\end{array}$ & $\begin{array}{l}.027^{*} \\
(.016)\end{array}$ & $\begin{array}{l}-.025 \\
(.024)\end{array}$ & $\begin{array}{l}.030 \\
(.020)\end{array}$ & $\begin{array}{l}.070 * * \\
(.031)\end{array}$ & $\begin{array}{l}.002 \\
(.030)\end{array}$ & $\begin{array}{l}.031^{*} \\
(.018)\end{array}$ & $\begin{array}{l}-.006 \\
(.021)\end{array}$ \\
\hline $\begin{array}{l}\text { Value share of agrifood } \\
\text { commodities sold, to total } \\
\text { production value }\end{array}$ & $\begin{array}{l}-.012 \\
(.013)\end{array}$ & $\begin{array}{l}-.003 \\
(.014)\end{array}$ & $\begin{array}{l}-.018 \\
(.025)\end{array}$ & & & $\begin{array}{l}-.019 \\
(.018)\end{array}$ & $\begin{array}{l}.002 \\
(.022)\end{array}$ \\
\hline Proximity to market & $\begin{array}{c}.012 \\
(.014)\end{array}$ & $\begin{array}{l}.020 \\
(.026)\end{array}$ & $\begin{array}{l}.063 * * \\
(.034)\end{array}$ & $\begin{array}{c}.054 \\
(.045)\end{array}$ & $\begin{array}{c}.079 \\
(.060)\end{array}$ & $\begin{array}{c}.023 \\
(.022)\end{array}$ & $\begin{array}{l}.017 \\
(.023)\end{array}$ \\
\hline
\end{tabular}

\subsubsection{Results on other covariates}

Our primary interests are in the estimation of EOS, rather than the coefficients of other control variables. We summarize their signs and statistical significance in Appendix Table 9 through Table 11, for both LR-Primal models and Dual models (for the cases of 50\% thresholds) and SR-Primal models. ${ }^{4}$ In the primal models, positive (negative) signs indicate that positive (negative) associations between the variable and the input distance function, or greater (less) savings in inputs used given the output level. Thus, positive (negative) signs indicate greater (lower) technical efficiency. In contrast, in the dual models, positive (negative) signs indicate higher production costs (given the output levels).

Overall, all variables have statistically significant coefficients in at least one model, providing justifications for their inclusions. Furthermore, the signs of coefficients also vary

${ }^{4}$ Due to space limitation, we only present the results for the case in which food purchase share is used as market participation indicators. Other results are available from authors upon requests. 
across different outcomes of interests (agriculture vs. all non-agricultural activities, agriculture vs. non-agricultural enterprises, within agriculture), and models. These results highlight the complex economic characteristics of SFHs, and our analyses' abilities to separate these effects, from the effects of agrifood market participation, on EOS.

\section{Conclusions and policy implications}

Despite the growth of agrifood markets, and gradual structural transformation, SFHs persist in Asia. Such patterns are at odds with the views that market growth should encourage more specialization whereby SFHs' transition to either larger farmers or specialized non-farm households. Better understanding the relations between growing agrifood markets and SFHs is important in identifying the measures to improve their livelihoods in parallel with modernizing the food systems.

Using the panel household data in Vietnam, this study investigates how participation in agrifood markets affect SFHs' economies of scope (EOS) in diversifying into agriculture and non-agricultural income-earning activities. We find that, greater agrifood market participation proxied by the increased food purchase generally increases EOS between agriculture and nonagricultural activities at the household level. Moreover, it leads to greater labor productivity in agriculture, and also increases female household members' diversifications into both agriculture and non-agricultural income-earning activities. These effects are relatively stronger and more consistent than conventional indicators of agrifood product sales or proximity to the market. These findings provide technological explanations of why increased agrifood market participation may keep SFHs to diversify into agriculture and non-agricultural, and yet not entirely leave the ag sector (and specialize in the nonagricultural sector).

The findings have important policy implications. The conventional policy discussions on integrating SFHs into growing agrifood market have well recognized the income potentials of increased agrifood commodity sales for these SFHs, and the importance of investments (such as road infrastructure) to shorten the physical distance to the market for these SFHs. However, policies that facilitate SFHs' increased purchase of food items from the market can have further complementary effects on their livelihood improvements. Regarding SFHs not only as producers but also consumers, and conducting further research on their consumption behaviors and preferences, may be important. Price policies may need to balance the benefits for SFHs both as sellers and buyers. Finally, understanding such consumption-side benefits of agrifood markets for SFHs may also facilitate increased female-labor participation in the workforce, either in the agriculture or the non-agricultural sector. 


\section{References}

Asian Development Bank (ADB) (2012). Inclusive Growth, Full Employment, and Structural Change: Implications and Structural Change: Implications and Policies for Developing Asia, edited by J Felipe. Manila. ADB.

Alene A, V Manyong, G Omanya, HD Mignouna, M Bokanga \& G Odhiambo. (2008). Smallholder market participation under transactions costs: Maize supply and fertilizer demand in Kenya. Food Pol. 33, 318-328.

Amsler, C., Prokhorov, A., \& Schmidt, P. (2016). Endogeneity in stochastic frontier models. Journal of Econometrics, 190(2), 280-288.

Banerjee A, P Gertler \& M Ghatak. (2002). Empowerment and Efficiency: Tenancy Reform in West Bengal. Journal of Political Economy 110(2), 239-280.

Barrett CB. (2008). Smallholder market participation: concepts and evidence from eastern and southern Africa. Food Pol., 33, 299-317.

Bazzi, S., Gaduh, A., Rothenberg, A. D., \& Wong, M. (2016). Skill transferability, migration, and development: Evidence from population resettlement in Indonesia. American Economic Review, 106(9), 2658-2698.

Basu, S. (2008). Returns to scale measurement, in Durlauf, S.N. and Blume, L.E. (eds), The New Palgrave Dictionary of Economics, 2nd edn. The Palgrave Macmillan, New York.

Baumol, W.J., Panzar, J.G., Willig, R.D., 1982. Contestable Markets and the Theory of Industry Structure. Harcourt Brace Jovanovich, New York.

Chamberlain G. (1984). Panel Data. In Handbook of Econometrics, vol. 2, ed. Z Grilliches \& MD Intriligator, 1247-1318. Amsterdam: North-Holland.

Chavas JP. (2001). Chapter 5 Structural change in agricultural production: Economics, technology and policy. Handbook of Agricultural Economics 1 (Part A), 263-285.

Coelli, T.J., Perelman, S., 1996. Efficiency measurement, multioutput technologies and distance functions: with application to European railways. CREPP WP 96/05. Centre de Recherche en Economie Publique et Economie de la Population, UniversitC de Libge.

Coelli, T., \& Fleming, E. (2004). Diversification economies and specialisation efficiencies in a mixed food and coffee smallholder farming system in Papua New Guinea. Agricultural Economics, 31(2-3), 229-239.

de Janvry A, K Emerick, M Gonzalez-Navarro \& E Sadoulet. 2015. Delinking Land Rights from Land Use: Certification and Migration in Mexico. Amer. Econ. Rev. 105(10): 3125-49.

Deininger K, D Monchuk, H Nagarajan \& S Singh (2017) Does Land Fragmentation Increase the Cost of Cultivation? Evidence from India. J. Dev. Stud. 53:1, 82-98.

Dustmann, C., \& Rochina-Barrachina, M. E. (2007). Selection correction in panel data models: An application to the estimation of females' wage equations. Econometrics Journal, 10(2), 263-293.

Efron B. (1979). Bootstrap methods: another look at the jackknife. Ann. Statist. 7, 101-118.

Fafchamps M \& F Shilpi. (2003). The Spatial Division of Labour in Nepal. J. Devel. Stud. 39(6), 23-66.

Fafchamps, M. and Shilpi, F. (2008). Subjective welfare, isolation, and relative consumption. Journal of Development Economics 86, 43-60.

Fan Y, H Li \& G Miguez-Macho. (2013). Global Patterns of Groundwater Table Depth: A Stochastic Model of Applied Research. Science 339, 940C943.

FAO (Food and Agriculture Organization) /IIASA (International Institute for Applied Systems Analysis) /ISRIC (International Soil Reference and Information Centre)/ISSCAS (Institute of Soil Science - Chinese Academy of Sciences) /JRC (Joint Research Centre of the 
European Commission). 2012. "Harmonized World Soil Database (version 1.2)." Rome: FAO; Laxenburg, Austria: IIASA. http://webarchive.iiasa.ac.at/Research/LUC/ExternalWorld-soil-database/HTML/.

Feder, G., Just, R., \& Zilberman, D. (1985). Adoption of agricultural innovations in developing countries: A survey. Economic Development and Cultural Change, 33(2), 255-298.

Freedman D. (1981). Bootstrapping regression models. Annals of Statistics 9, 1218-1228.

Flores-Moya, P., Evenson, R.E. and Hayami, Y. 1978, Social returns to rice research in the Philippines: domestic benefits and foreign spillover. Economic Development and Cultural Change 26(3), pp. 591-607.

Goetz, S. J. (1992). A selectivity model of household food marketing behavior in sub-Saharan Africa. Am. J. Agric. Econ. 74(2), 444-452.

Gollin, D., Jedwab, R., Vollrath, D., 2016. Urbanization with and without industrialization. $J$. Econ. Growth 21 (1), 35-70.

Ha, T. M., Bosch, O. J., Nguyen, N. C., \& Trinh, C. T. (2017). System dynamics modelling for defining livelihood strategies for women smallholder farmers in lowland and upland regions of northern Vietnam: A comparative analysis. Agricultural systems, 150, 12-20.

Haggblade, S., Hazell, P., \& Brown, J. (1989). Farm-non-farm linkages in rural Sub-Saharan Africa. World Development, 17(8), 1173-1201.

Heltberg R \& F Tarp. (2002). Agricultural supply response and poverty in Mozambique. Food Pol., 27(1), 103-124.

International Food Policy Research Institute (IFPRI). (2019). Global Food Policy Report 2019. Washington DC. IFPRI.

Irz, X., \& Thirtle, C. (2004). Dual technological development in Botswana agriculture: A stochastic input distance function approach. Journal of Agricultural Economics, 55(3), 455478.

Jacoby HG. (1993). Shadow wages and peasant Family Labour Supply: An Econometric Application to the Peruvian Sierra. Review of Economic Studies 60(4): 903-21.

Jayne T, D Mather \& E Mghenyi. (2010). Principal Challenges Confronting Smallholder Agriculture in Sub-Saharan Africa. World Devel. 38(10), 1384-1398.

Jayne TS, J Chamberlin, L Traub, N Sitko, M Muyanga, FK Yeboah, W Anseeuw, A Chapoto, A Wineman, C Nkonde \& R Kachule. (2016). Africa's changing farm size distribution patterns: the rise of medium-scale farms. Agricultural Economics 47(S1), 197-214.

Jin, S., Rozelle, S., Alston, J., Huang, J., 2005. Economies of scale and scope and the economic efficiency of China's agricultural research system. Int. Econ. Rev. 46 (3), 1033-1057.

Keefer P \& S Khemani. (2014). Mass media and public education: The effects of access to community radio in Benin. Journal of Development Economics 109, 57-72.

Key, N., Sadoulet, E., \& de Janvry, A. (2000). Transactions costs and agricultural household supply response. Am. J. Agric. Econ. 82(2), 245-259.

Lanjouw JO \& P Lanjouw. (2001). The rural non-farm sector: issues and evidence from developing countries. Agric. Econ. 26(1), 1-23.

Larsson, R., 2005. Crisis and potential in smallholder food production-evidence from microlevel. In: Djurfeldt, G., Holmen, H., Jirstrom, M., Larsson, R. (Eds.), The African Food Crisis. Lessons from the Asian Green Revolution. CABI Publishing, Wallingford.

Liu Y, C Barrett, T Pham \& W Violette. (2019). The Intertemporal Evolution of Agriculture and Labor over a Rapid Structural Transformation: Lessons from Vietnam. Mimeo. 
McCaig, B., \& Pavcnik, N. (2016). Moving out of agriculture: structural change in Vietnam. In Structural change, fundamentals, and growth: A framework and case studies, M McMillan, D Rodrik \& C Sepúlveda (eds.). Washington DC. IFPRI.

Mundlak Y. (1978). On the Pooling of Time Series and Cross Section Data. Econometrica 46: 69-85.

Munshi K. (2004). Social Learning in a Heterogeneous Population: Technology Diffusion in the Indian Green Revolution. J. Dev. Econ.73(1):185--213.

Nguyen, H. Q. (2017). Analyzing the economies of crop diversification in rural Vietnam using an input distance function. Agricultural systems 153, 148-156.

National Oceanic and Atmospheric Administration (NOAA). Terrestrial Air Temperature and Precipitation: Monthly and Annual Time Series. Available at https://www.esrl.noaa.gov/psd/data/gridded/data.UDel AirT Precip.html\#detail.

Otsuka, K., Liu, Y., \& Yamauchi, F. (2016). Growing advantage of large farms in Asia and its implications for global food security. Global Food Security, 11, 5-10.

Ouma, E., Jagwe, J., Obare, G. A., \& Abele, S. (2010). Determinants of smallholder farmers' participation in banana markets in Central Africa: the role of transaction costs. Agricultural Economics, 41(2), 111-122.

Puhani PA. (2000). The heckman correction for sample selection and its critique. Journal of Economic Surveys 14, 53-68.

Ravallion, M., \& Van de Walle, D. (2008). Does rising landlessness signal success or failure for Vietnam's agrarian transition? J. Devel. Econ. 87(2), 191-209.

Reardon, T. (2015). The hidden middle: the quiet revolution in the midstream of agrifood value chains in developing countries. Oxford Review of Economic Policy 31(1), 45-63.

Reardon T \& P Timmer. (2007). Transformation of markets for agricultural output in developing countries since 1950: How has thinking changed? In R. Evenson, P. Pingali, \& T. Schultz (Eds.), Handbook of Agricultural Economics 3, 2807-2855.

Renner, S., Glauben, T., \& Hockmann, H. (2014). Measurement and decomposition of flexibility of multi-output firms. European Review of Agricultural Economics, 41(5), 745-773.

Rigg, J., Salamanca, A., \& Thompson, E. C. (2016). The puzzle of East and Southeast Asia's persistent smallholder. Journal of Rural Studies 43, 118-133.

Rigg, J., Salamanca, A., Phongsiri, M., \& Sripun, M. (2018). More farmers, less farming? Understanding the truncated agrarian transition in Thailand. World Development, 107, 327337.

Schultz, T. W. 1953. The Economic Organization of Agriculture. New York: McGraw-Hill.

Sheng, Y., Zhao, S., Nossal, K., Zhang, D., 2015. Productivity and farm size in Australian agriculture: reinvestigating the returns to scale. Aust. J. Agric. Resour. Econ. 59 (1), 16-38.

Skoufias E. (1994). Using Shadow Wages to Estimate Labor Supply of Agricultural Households. Amer. J. Agr. Econ. 76(2): 215-27.

Squires, D., 1987. Long-run profit functions for multiproduct firms. Am. J. Agric. Econ. 69(3), $558-569$.

Takeshima H. (2017). Custom-hired tractor services and returns to scale in smallholder agriculture: A production function approach. Agricultural Economics 48(3), 363-372.

Takeshima H. (2018). Mechanize or exit farming? Multiple-treatment-effects model and external validity of adoption impacts of mechanization among Nepalese smallholders. Review of Development Economics 22(4), 1620-1641.

Takeshima H \& PK Joshi. (2019). Overview of the agricultural modernization in Southeast Asia. IFPRI Discussion Paper 01819. 
Takeshima H, M Amare \& G Mavrotas. (2018). The role of agricultural productivity in non-farm activities in Nigeria: Effects on sector orientation and factor intensity. IFPRI Discussion Paper 01761.

Takeshima H, P Hatzenbuehler, H Edeh. (2020). Effects of agricultural mechanization on economies of scope in crop production in Nigeria. Agricultural Systems 177, 102691.

Weber MT, JM Staatz, JS Holtzman, EW Crawford \& RH Bernsten. (1988). Informing food security decisions in Africa: empirical analysis and policy dialogue. Am. J. Agric. Econ. 70(5), 1044-1052.

World Bank. (2007). World Development Report 2008: Agriculture for Development. Washington, DC: World Bank.

Yamauchi F, K Otsuka \& J Huang. (2020). Changing Farm Size and Agricultural Development in East Asia, in Agricultural Development: New Perspectives in a Changing World, $\mathrm{K}$ Otsuka \& S Fan (eds). IFPRI, forthcoming.

Zanello G. (2012). Mobile Phones and Radios: Effects on Transactions Costs and Market Participation for Households in Northern Ghana. J. Agr. Econ. 63(3), 694-714. 


\section{Appendix}

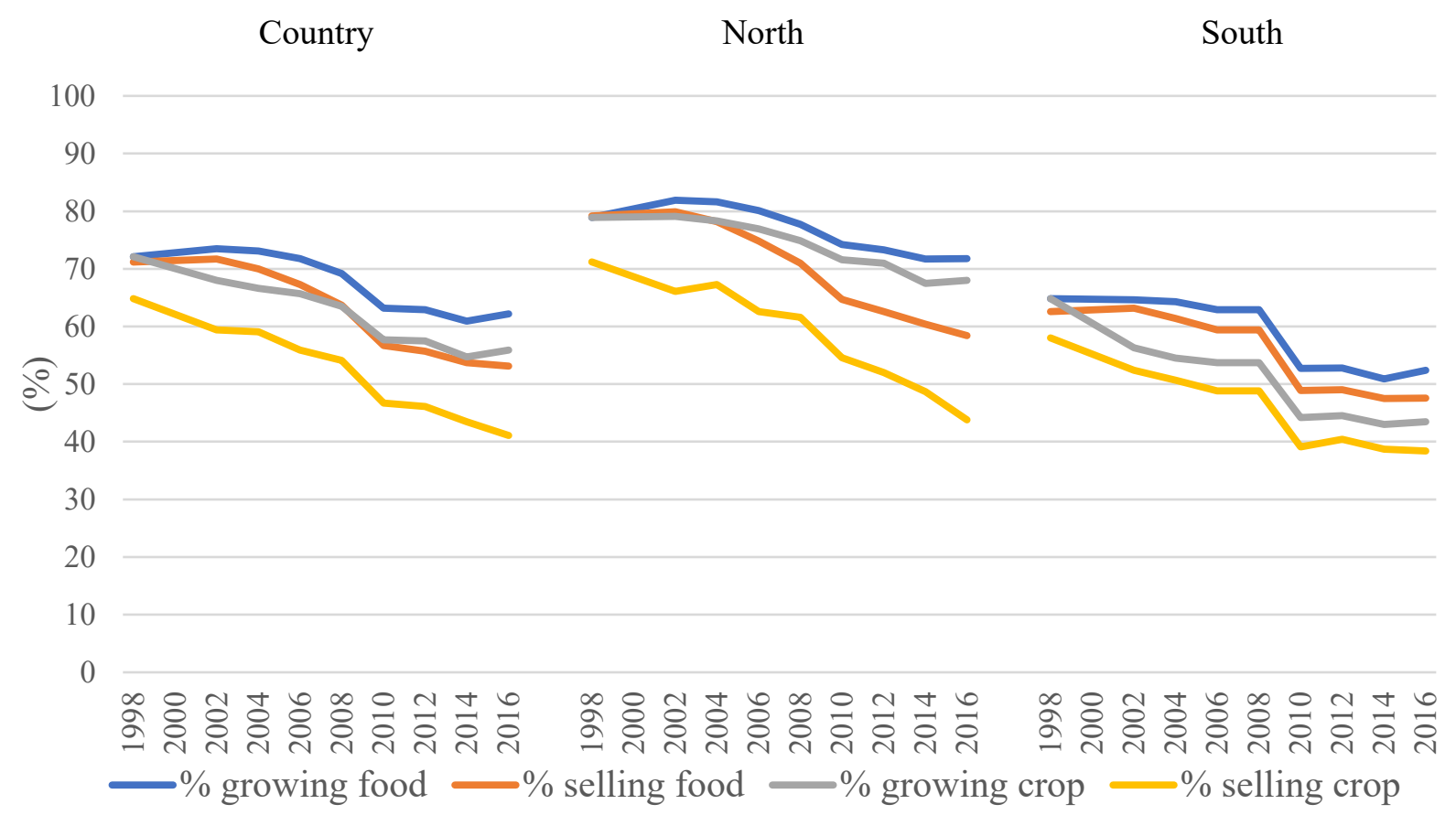

Figure 1. Share (\%) of Vietnamese households growing food, selling food, growing crops, selling crops

Source: Authors.

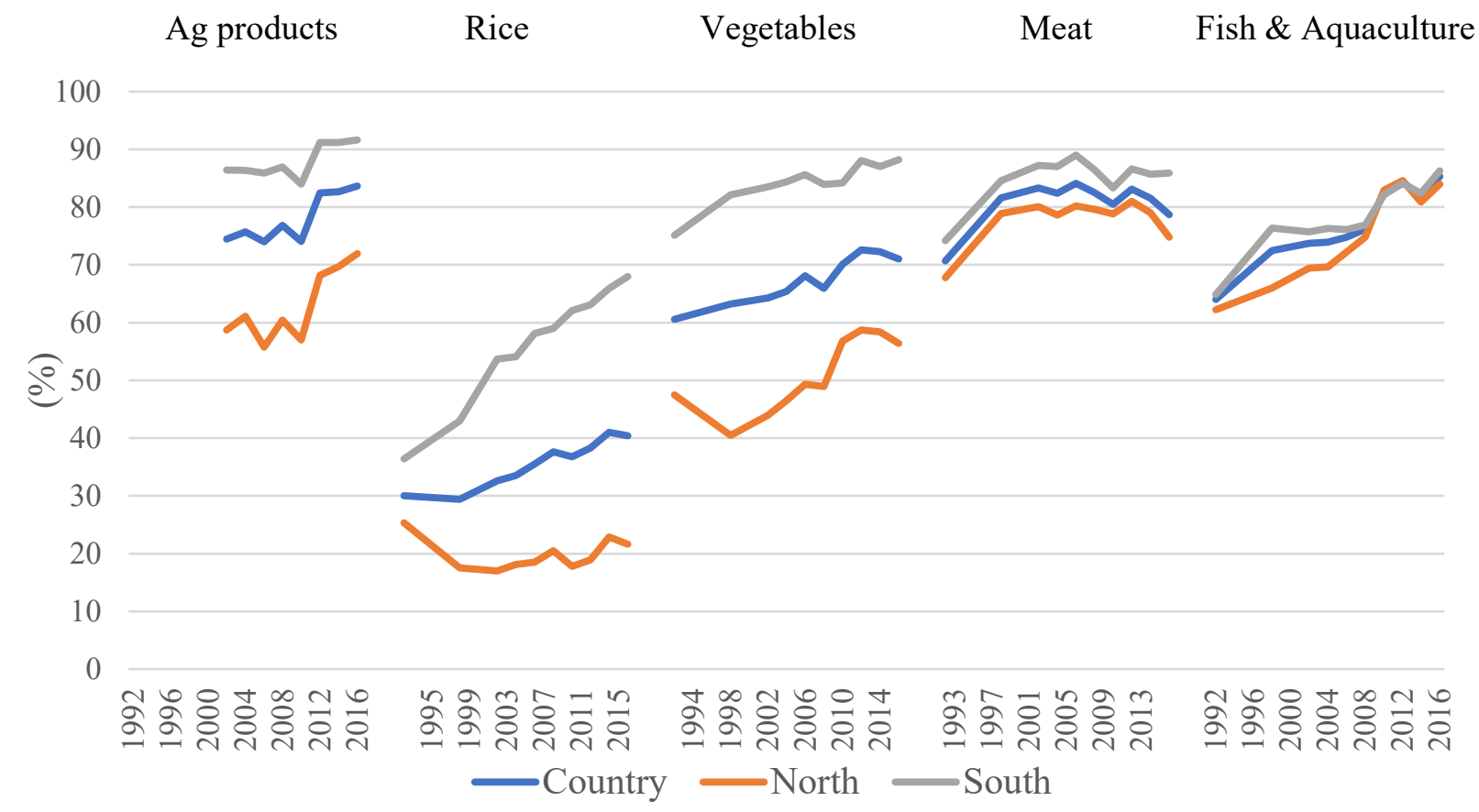

Figure 2. Share (\%) of production sold in the market in Vietnam

Source: Authors. 


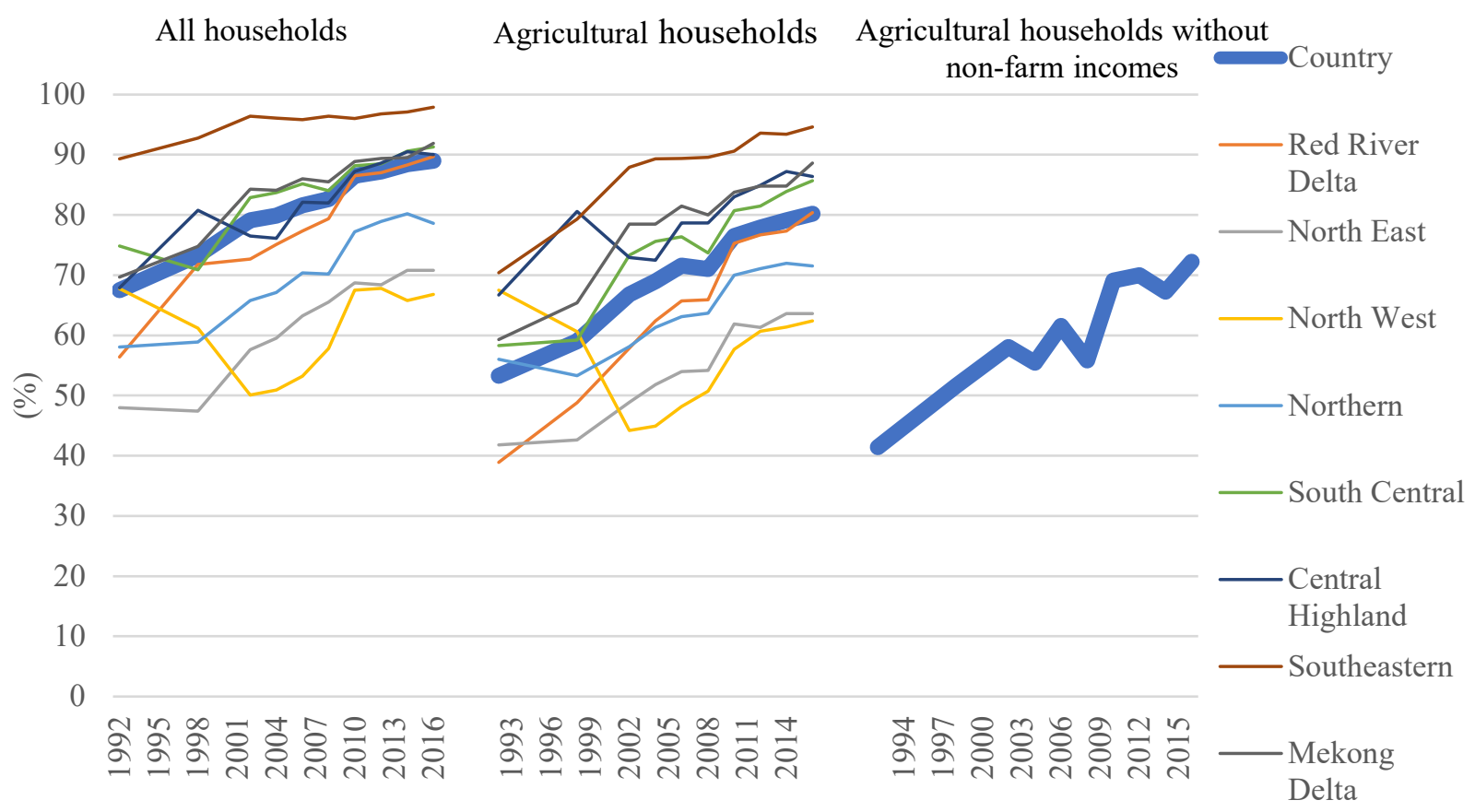

Figure 3. Share (\%) of purchased food to total food consumed (value) Source: Authors.

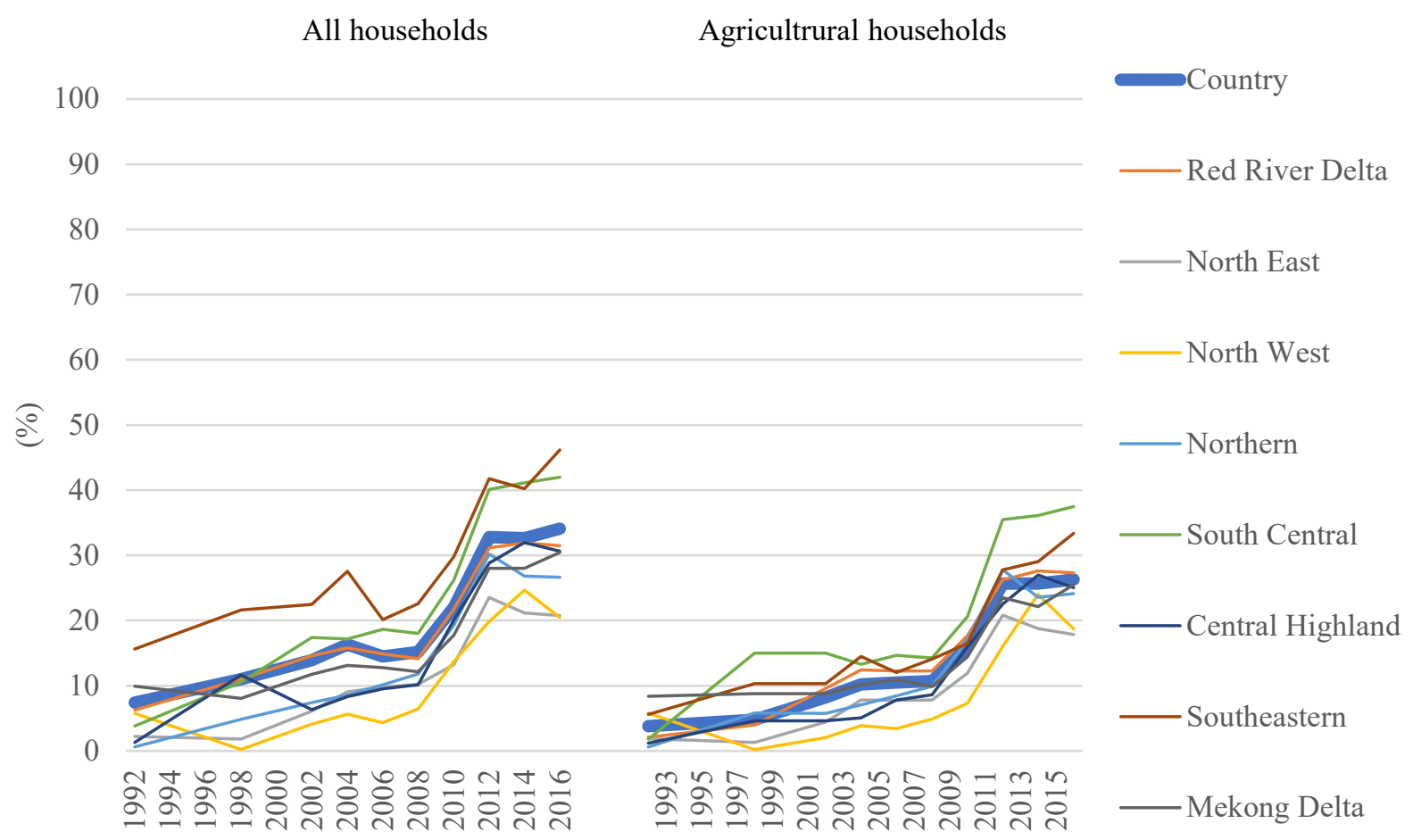

Figure 4. Share (\%) of eating out food to total food consumed (value) Source: Authors. 


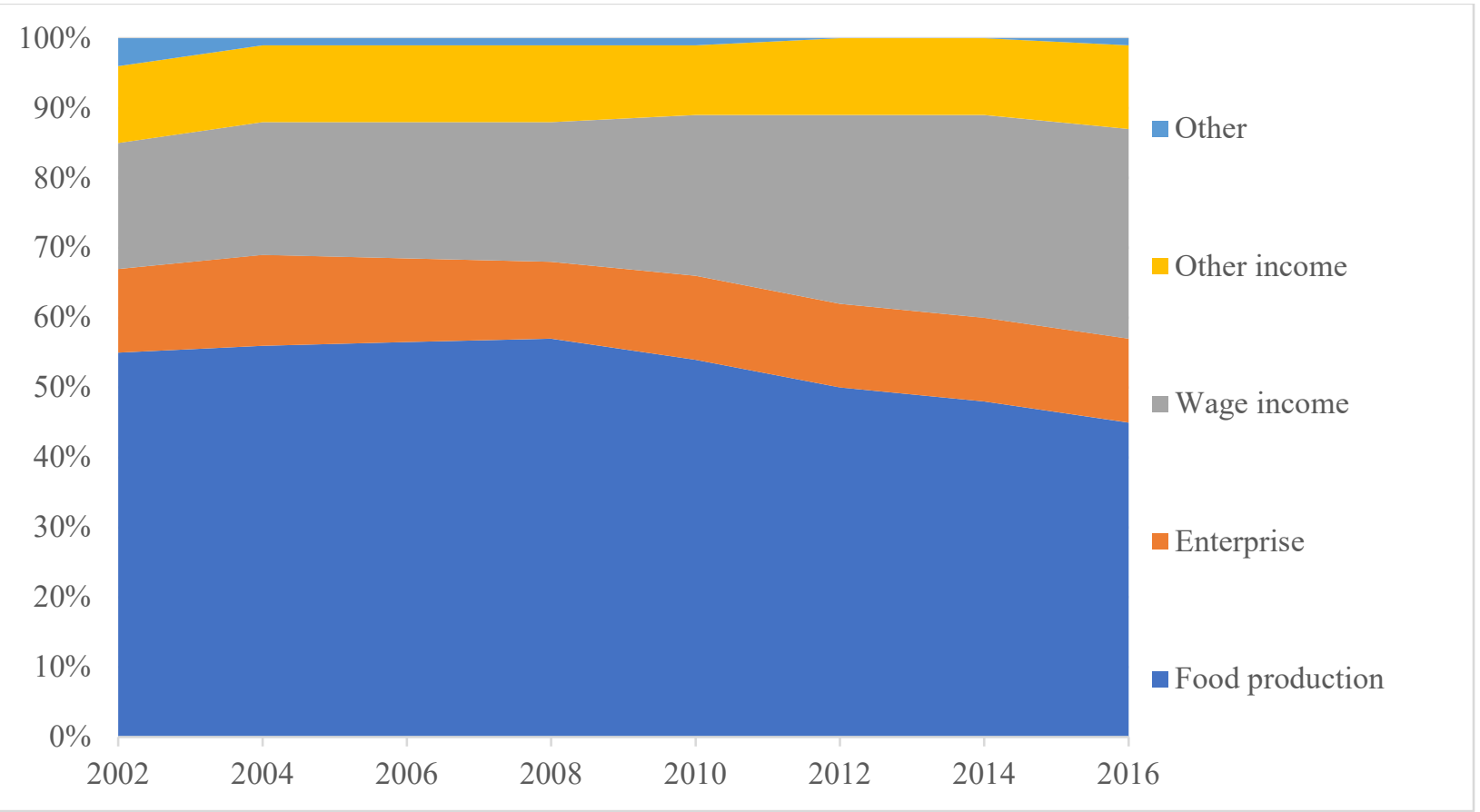

Figure 5. Revenue shares (\%) of different household activities - among smallholders Source: Authors.

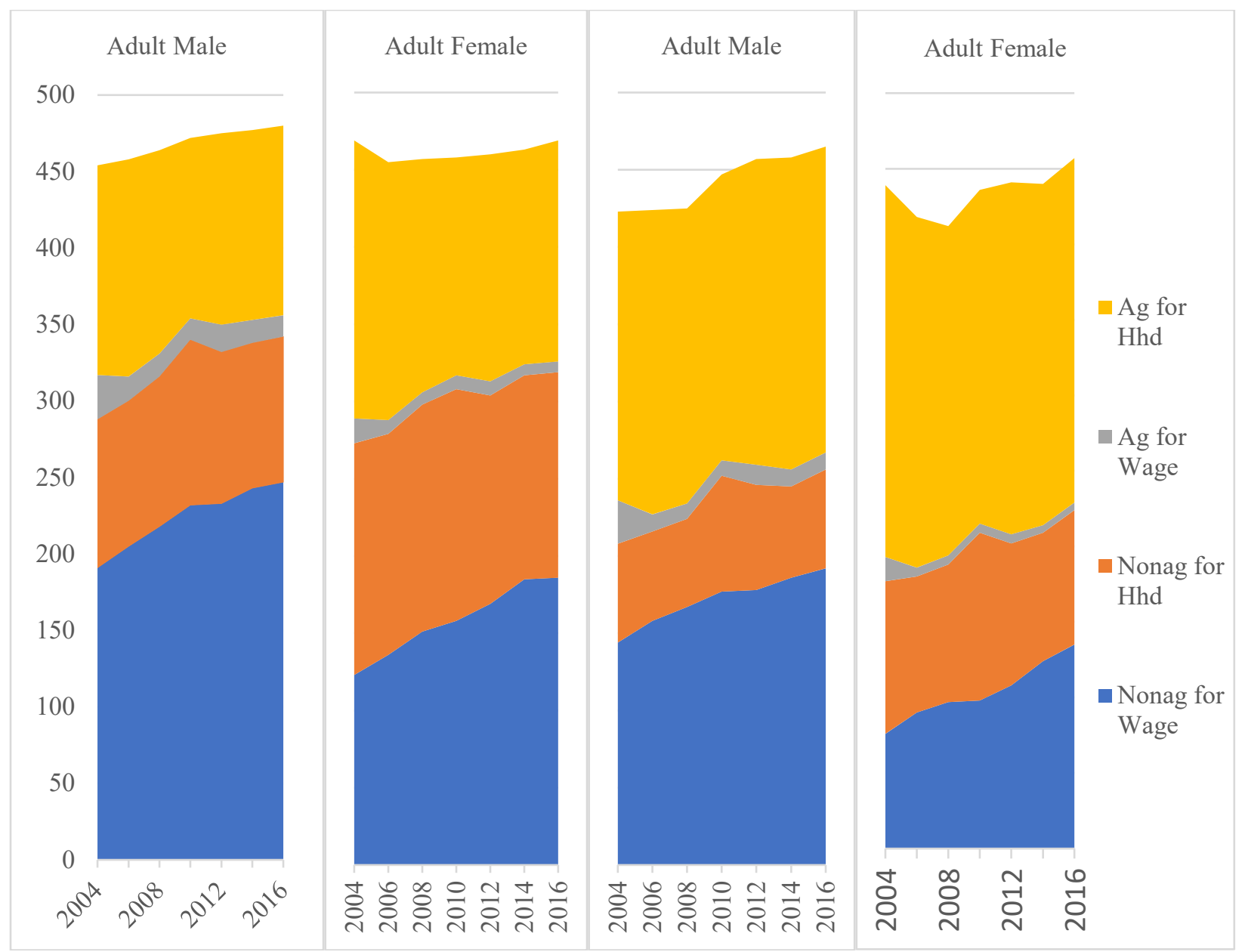

Figure 6. Household labor use by sectors, gender (person-days / year) Source: Authors. 

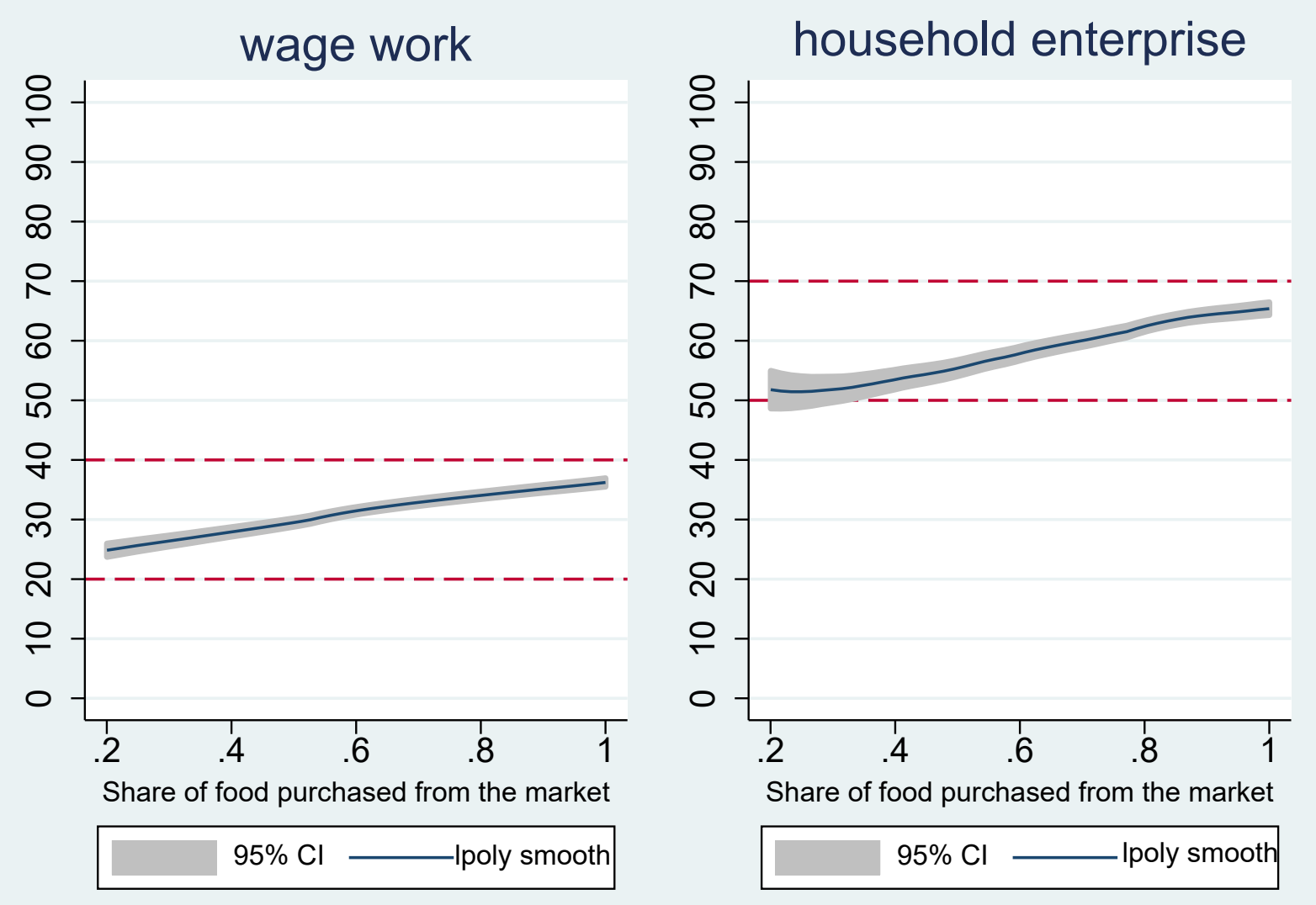

Figure 7. Female share of non-agricultural work (wage work and household enterprise work) among agricultural households

Source: Authors.

Note: Vertical axis is the female share (\%) of labor work provided by household members in wage work and household enterprise work. 


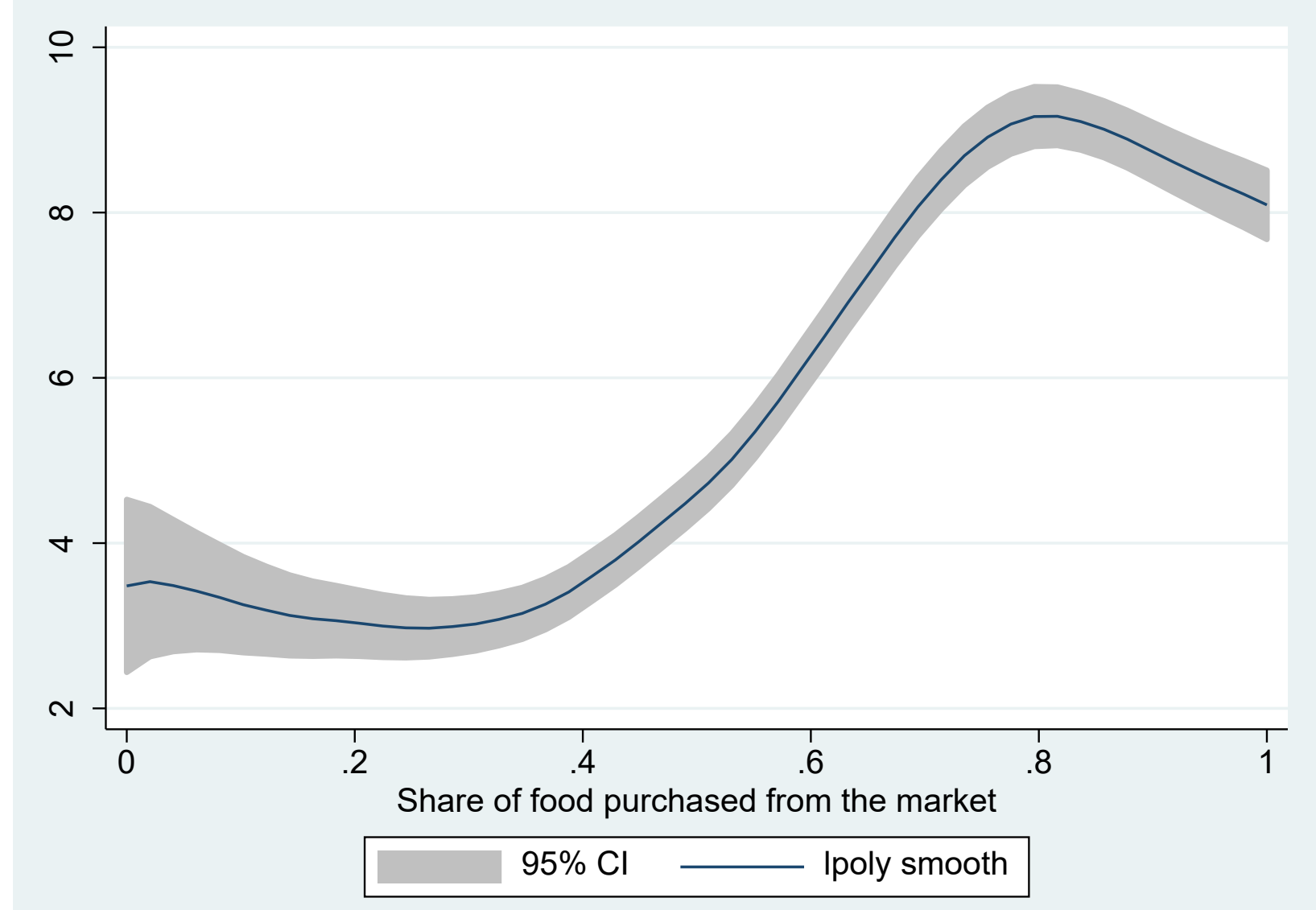

Figure 8. Share of adult female members, engaging in both agricultural and nonagricultural activities (among farm households)

Source: Authors.

Note: Vertical axis indicates the share (\%) of adult female members, who are engaging in both agricultural and nonagricultural activities 


\section{Appendix: Statistically significant signs for other variables (for the case of food purchase share as market participation indicators)}

Table 9. LR-primal

\begin{tabular}{|c|c|c|c|c|c|c|}
\hline \multirow[t]{3}{*}{ Variables } & \multicolumn{6}{|c|}{$\begin{array}{c}\text { Sectors of household income earning activities for which EOS, and effect of market } \\
\text { participation is estimated }\end{array}$} \\
\hline & \multicolumn{2}{|c|}{$\begin{array}{l}\text { Agriculture vs. all non- } \\
\text { agricultural activities }\end{array}$} & \multicolumn{2}{|c|}{$\begin{array}{l}\text { Agriculture vs. non- } \\
\text { agricultural enterprises of } \\
\text { the household }\end{array}$} & \multicolumn{2}{|c|}{ Within agriculture } \\
\hline & $\begin{array}{c}\text { Intensive } \\
\text { market } \\
\text { participants }\end{array}$ & $\begin{array}{l}\text { Subsistence } \\
\text { households }\end{array}$ & $\begin{array}{l}\text { Intensive } \\
\text { market } \\
\text { participants }\end{array}$ & $\begin{array}{l}\text { Subsistence } \\
\text { households }\end{array}$ & $\begin{array}{l}\text { Intensive } \\
\text { market } \\
\text { participants }\end{array}$ & $\begin{array}{l}\text { Subsistence } \\
\text { households }\end{array}$ \\
\hline Output 1 & - & & & + & & + \\
\hline Output 2 & & & + & & & - \\
\hline Other inputs & + & & & & & - \\
\hline Capital & & & - & & & \\
\hline Land & & - & - & - & - & - \\
\hline Output $1 \times$ Output 1 & - & - & - & & - & - \\
\hline Output $1 \times$ Output 2 & + & + & + & & + & + \\
\hline Output $1 \times$ Other inputs & - & - & - & - & & + \\
\hline Output $1 \times$ Capital & - & & & + & & - \\
\hline Output $1 \times$ Land & - & & & + & - & \\
\hline Output $2 \times$ Output 2 & - & - & - & - & - & - \\
\hline Output $2 \times$ Other inputs & + & + & + & + & & + \\
\hline Output $2 \times$ Capital & + & & & & + & \\
\hline Output $2 \times$ Land & - & - & & - & & - \\
\hline Other inputs $\times$ Other inputs & + & - & + & & + & \\
\hline Other inputs $\times$ Capital & - & & & & & \\
\hline Other inputs $\times$ Land & & + & - & + & - & \\
\hline Capital $\times$ Capital & & & + & & + & + \\
\hline Capital $\times$ Land & - & & - & - & & - \\
\hline Land $\times$ Land & - & - & - & - & - & - \\
\hline \multicolumn{7}{|l|}{ Rainfall (current) } \\
\hline Temperature (current) & - & - & - & - & - & - \\
\hline Disaster & - & - & - & - & & \\
\hline Male $>60$ & - & - & - & & & - \\
\hline Male $20-60$ & - & - & - & - & - & - \\
\hline Male 6-19 & - & & & & - & \\
\hline Male $0-5$ & - & & - & & - & \\
\hline Female $>60$ & & - & + & - & & \\
\hline Female $20-60$ & - & - & & - & & - \\
\hline Female $6-19$ & & - & & - & & \\
\hline \multicolumn{7}{|l|}{ Female $0-5$} \\
\hline Female head & + & + & + & & & + \\
\hline \multicolumn{7}{|l|}{ Education of head } \\
\hline \multicolumn{7}{|l|}{ Education of WAM } \\
\hline Road & & & & - & & \\
\hline \multicolumn{7}{|l|}{ Market } \\
\hline Post Office & & & & & + & \\
\hline \multicolumn{7}{|l|}{ Bank } \\
\hline Radio station & & - & & - & & \\
\hline Internet & - & & & & & \\
\hline Asset & - & - & - & - & & - \\
\hline \multicolumn{7}{|l|}{ Fridge } \\
\hline Cooking & & & & & & + \\
\hline Mobile phone & + & - & & & & \\
\hline Extension & & & & & & + \\
\hline Wage (male) & - & & & & & \\
\hline \multicolumn{7}{|l|}{ Wage (female) } \\
\hline Fertilizer price & + & & & & & \\
\hline
\end{tabular}




\begin{tabular}{|c|c|c|c|c|c|c|}
\hline \multirow[t]{3}{*}{ Variables } & \multicolumn{6}{|c|}{$\begin{array}{c}\text { Sectors of household income earning activities for which EOS, and effect of market } \\
\text { participation is estimated }\end{array}$} \\
\hline & \multicolumn{2}{|c|}{$\begin{array}{l}\text { Agriculture vs. all non- } \\
\text { agricultural activities }\end{array}$} & \multicolumn{2}{|c|}{$\begin{array}{c}\text { Agriculture vs. non- } \\
\text { agricultural enterprises of } \\
\text { the household }\end{array}$} & \multicolumn{2}{|c|}{ Within agriculture } \\
\hline & $\begin{array}{c}\text { Intensive } \\
\text { market } \\
\text { participants }\end{array}$ & $\begin{array}{l}\text { Subsistence } \\
\text { households }\end{array}$ & $\begin{array}{l}\text { Intensive } \\
\text { market } \\
\text { participants } \\
\end{array}$ & $\begin{array}{l}\text { Subsistence } \\
\text { households }\end{array}$ & $\begin{array}{l}\text { Intensive } \\
\text { market } \\
\text { participants } \\
\end{array}$ & $\begin{array}{l}\text { Subsistence } \\
\text { households }\end{array}$ \\
\hline Land price & - & & & & & \\
\hline \multicolumn{7}{|l|}{ Rice price } \\
\hline \multicolumn{7}{|l|}{ c_n_eff $10 y$} \\
\hline \multicolumn{7}{|l|}{ c_n_eff_10_yc } \\
\hline c_n_emp_eff 5 & - & & & + & & \\
\hline Health & - & & - & + & - & \\
\hline Relief program & & + & + & + & + & + \\
\hline \multicolumn{7}{|l|}{ Land certificate } \\
\hline Land spending & - & + & - & & - & - \\
\hline $\begin{array}{l}\text { Year dummy * province } \\
\text { dummy }\end{array}$ & \multicolumn{6}{|c|}{ Included } \\
\hline Household fixed effects & \multicolumn{6}{|c|}{ Included } \\
\hline Intercept & \multicolumn{6}{|c|}{ Included } \\
\hline Sample size & \multicolumn{6}{|c|}{10,864} \\
\hline
\end{tabular}

Source: Authors.

"Intensive market participants" = households with market participation indicators above sample median; "Subsistence households" = = households with market participation indicators below sample median

Variables notations:

Output 1 = agriculture, Output 2 = non-agricultural income earning activities; For EOS within agriculture, Output 1 = rice; Output 2 = non-rice agricultural commodities.

WAM = working-age members; c_n_eff_10_y $=$ whether there is firms/factories/enterprises in the community; c_n_eff_10_yc $=$ whether there is firms/ factories /enterprises in the community that employs workers from this community; c_n_emp_eff_5 = Number of workers employed in the 5 largest non-farm firms/ factories / enterprises in the community 
Table 10. SR-primal

\begin{tabular}{|c|c|c|c|c|c|c|}
\hline \multirow[t]{3}{*}{ Variables } & \multicolumn{6}{|c|}{$\begin{array}{c}\text { Sectors of household income earning activities for which EOS, and effect of } \\
\text { market participation is estimated }\end{array}$} \\
\hline & \multicolumn{2}{|c|}{$\begin{array}{l}\text { Agriculture vs. all non- } \\
\text { agricultural activities }\end{array}$} & \multicolumn{2}{|c|}{$\begin{array}{l}\text { Agriculture vs. non- } \\
\text { agricultural enterprises } \\
\text { of the household }\end{array}$} & \multicolumn{2}{|c|}{ Within agriculture } \\
\hline & & $\begin{array}{l}\text { Interaction } \\
\text { term with } \\
\text { market } \\
\text { participation } \\
\text { indicator }\end{array}$ & & $\begin{array}{l}\text { Interaction } \\
\text { term with } \\
\text { market } \\
\text { participation } \\
\text { indicator } \\
\end{array}$ & & $\begin{array}{l}\text { Interaction } \\
\text { term with } \\
\text { market } \\
\text { participation } \\
\text { indicator }\end{array}$ \\
\hline Market participation indicator & + & & + & & + & \\
\hline \multicolumn{7}{|l|}{ Output 1} \\
\hline Output 2 & - & & & & & \\
\hline Other inputs & + & & + & & + & - \\
\hline Capital & + & & & & & \\
\hline Land & & + & + & + & & + \\
\hline Output $1 \times$ Output 1 & & - & & - & - & \\
\hline Output $1 \times$ Output 2 & & + & & & & + \\
\hline Output $1 \times$ Other inputs & & & - & & & \\
\hline Output $1 \times$ Capital & & & & & + & - \\
\hline Output $1 \times$ Land & & & & & - & \\
\hline Output $2 \times$ Output 2 & - & + & - & + & - & \\
\hline Output $2 \times$ Other inputs & + & - & + & - & + & - \\
\hline Output $2 \times$ Capital & & & & & - & + \\
\hline Output $2 \times$ Land & - & + & - & + & - & \\
\hline \multicolumn{7}{|l|}{ Other inputs $\times$ Other inputs } \\
\hline Other inputs $\times$ Capital & & & - & & - & \\
\hline Other inputs $\times$ Land & + & - & + & - & + & - \\
\hline Capital $\times$ Capital & & & & & + & - \\
\hline \multicolumn{7}{|l|}{ Capital $\times$ Land } \\
\hline Land $\times$ Land & - & + & - & + & - & + \\
\hline Rainfall (current) & & + & & & + & \\
\hline Temperature (current) & & & & & + & \\
\hline \multicolumn{7}{|l|}{ Disaster } \\
\hline \multicolumn{7}{|l|}{ Male $>60$} \\
\hline Male $20-60$ & & & & & & - \\
\hline Male $6-19$ & & & & & & - \\
\hline \multicolumn{7}{|l|}{ Male $0-5$} \\
\hline \multicolumn{7}{|l|}{ Female $>60$} \\
\hline Female $20-60$ & - & & - & & - & \\
\hline Female $6-19$ & - & & - & & - & \\
\hline \multicolumn{7}{|l|}{ Female $0-5$} \\
\hline Female head & + & & + & & & \\
\hline Education of head & & & & & & - \\
\hline \multicolumn{7}{|l|}{ Education of WAM } \\
\hline Road & - & & & & - & \\
\hline \multicolumn{7}{|l|}{ Market } \\
\hline \multicolumn{7}{|l|}{ Post Office } \\
\hline \multicolumn{7}{|l|}{ Bank } \\
\hline Radio station & - & & - & & - & \\
\hline \multicolumn{7}{|l|}{ Internet } \\
\hline \multicolumn{7}{|l|}{ Asset } \\
\hline \multicolumn{7}{|l|}{ Fridge } \\
\hline Cooking & & & & & & \\
\hline Mobile phone & & & & & & \\
\hline Extension & & & & & & \\
\hline Wage (male) & & & & & + & \\
\hline Wage (female) & & & & & - & \\
\hline Fertilizer price & & & & & - & \\
\hline
\end{tabular}




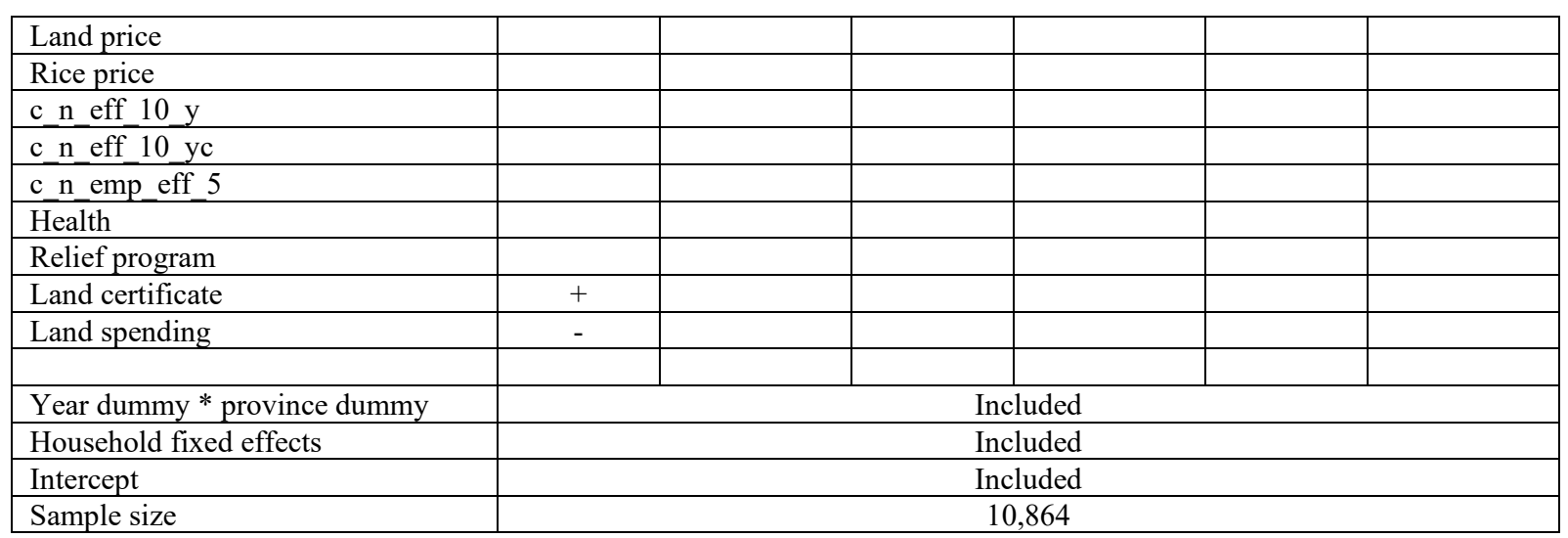

Source: Authors.

Variables notations: Output 1 = agriculture, Output 2 = non-agricultural income earning activities; For EOS within agriculture, Output 1 = rice; Output 2 = non-rice agricultural commodities.

$\mathrm{WAM}=$ working-age members; c_n_eff_10_y $=$ whether there is firms/factories/enterprises in the community; c_n_eff_10_yc $=$ whether there is firms/ factories /enterprises in the community that employs workers from this community; c_n_emp_eff_5

$=$ Number of workers employed in the 5 largest non-farm firms/ factories / enterprises in the community. 
Table 11. Dual model

\begin{tabular}{|c|c|c|c|c|c|c|c|c|c|c|c|c|c|c|c|c|c|c|}
\hline \multirow[b]{4}{*}{ Dependent variables } & \multicolumn{18}{|c|}{$\begin{array}{l}\text { Sector of household income earning activities for which EOS, and effect of market } \\
\text { participation is estimated }\end{array}$} \\
\hline & \multicolumn{6}{|c|}{$\begin{array}{l}\text { Agriculture vs. all non- } \\
\text { agricultural activities }\end{array}$} & \multicolumn{6}{|c|}{$\begin{array}{c}\text { Agriculture vs. non- } \\
\text { agricultural enterprises of } \\
\text { the household }\end{array}$} & \multicolumn{6}{|c|}{ Within agriculture } \\
\hline & \multicolumn{3}{|c|}{$\begin{array}{c}\text { Intensive } \\
\text { market } \\
\text { participants } \\
\end{array}$} & \multicolumn{3}{|c|}{$\begin{array}{l}\text { Subsistence } \\
\text { households }\end{array}$} & \multicolumn{3}{|c|}{$\begin{array}{c}\text { Intensive } \\
\text { market } \\
\text { participants }\end{array}$} & \multicolumn{3}{|c|}{$\begin{array}{l}\text { Subsistence } \\
\text { households }\end{array}$} & \multicolumn{3}{|c|}{$\begin{array}{c}\text { Intensive } \\
\text { market } \\
\text { participants }\end{array}$} & \multicolumn{3}{|c|}{$\begin{array}{l}\text { Subsistence } \\
\text { households }\end{array}$} \\
\hline & $\mathbf{A}$ & B & $\mathbf{C}$ & $\mathbf{A}$ & $\mathbf{B}$ & $\mathbf{C}$ & $\mathbf{A}$ & B & $\mathbf{C}$ & $\mathbf{A}$ & B & $\mathbf{C}$ & $\mathbf{A}$ & B & $\mathbf{C}$ & $\mathbf{A}$ & $\mathbf{B}$ & $\mathbf{C}$ \\
\hline Output 1 & & + & + & & & & & + & + & & + & + & & - & + & & - & + \\
\hline Output $1 \times$ Output 1 & & + & + & & & & & + & + & & & + & & + & + & & + & + \\
\hline Output 2 & + & & + & & & & - & & & - & & - & + & & + & + & & + \\
\hline Output $2 \times$ Output 2 & & & - & & & & + & & - & + & & & - & & - & - & & - \\
\hline Output $1 \times$ Output 2 & & & - & & & & & & - & & & - & & & - & & & - \\
\hline $\mathrm{V} \times$ Rainfall (current) & + & & & + & - & & + & & & & - & - & + & - & + & & & \\
\hline $\mathrm{V} \times$ Temperature (current) & & & - & - & & & & & - & - & & & + & & & + & & \\
\hline $\mathrm{V} \times$ Disaster & & & + & + & & + & & & + & & & & - & & & & & \\
\hline $\mathrm{V} \times$ Male $>60$ & & & & - & & & & & & - & & & & + & & & - & \\
\hline $\mathrm{V} \times$ Male $20-60$ & & & & - & + & - & - & & - & - & + & - & & & & + & + & \\
\hline $\mathrm{V} \times$ Male $6-19$ & & + & & - & & & & + & & - & & & - & & & & + & \\
\hline $\mathrm{V} \times$ Male $0-5$ & & + & & - & & & & + & - & & & & - & - & & + & & \\
\hline $\mathrm{V} \times$ Female $>60$ & & - & & - & & - & & - & & & & & - & & + & & - & \\
\hline $\mathrm{V} \times$ Female $20-60$ & & - & & - & + & - & & - & & & + & & & & - & - & - & \\
\hline $\mathrm{V} \times$ Female $6-19$ & & & & & & & & & & + & & + & + & & & - & & \\
\hline $\mathrm{V} \times$ Female $0-5$ & & + & & & - & & & + & & & - & & & & & & & \\
\hline $\mathrm{V} \times$ Female head & & + & & & & + & & + & - & - & & & + & & - & & & \\
\hline $\mathrm{V} \times$ Education of head & & & & & + & & & & & & + & & & - & & - & - & \\
\hline $\mathrm{V} \times$ Education of WAM & & & & - & - & & & & + & & - & + & & & + & & + & \\
\hline $\mathrm{V} \times \mathrm{Road}$ & & + & & + & + & & & + & & & + & & & - & & - & & \\
\hline $\mathrm{V} \times$ Market & & - & + & & - & + & & - & & & - & & - & + & - & + & + & - \\
\hline $\mathrm{V} \times$ Post Office & + & & & - & & & & & & & & & & - & & & & + \\
\hline $\mathrm{V} \times \mathrm{Bank}$ & & + & & + & & & & + & & & & & & + & + & & + & \\
\hline $\mathrm{V} \times$ Radio station & & + & & & & & & + & & & & & & & + & & & \\
\hline $\mathrm{V} \times$ Internet & & + & + & & & - & & + & + & & & & - & & & & & \\
\hline $\mathrm{V} \times$ Asset & & & & - & & & & & & - & & - & & & & + & & \\
\hline $\mathrm{V} \times$ Fridge & & & & & & & & & & & & & + & & + & - & & \\
\hline $\mathrm{V} \times$ Cooking & & & - & + & & & & & & & & & & & & & & \\
\hline $\mathrm{V} \times$ Mobile phone & + & & + & + & & & & & & + & & & + & + & & & & \\
\hline $\mathrm{V} \times$ Extension & & + & + & & & + & & + & + & & & & + & + & + & & - & \\
\hline $\mathrm{V} \times$ Wage (male) & & - & & - & & & & - & & & & & + & & + & & & \\
\hline $\mathrm{V} \times$ Wage (female) & - & - & & - & & & - & - & & & & & & & - & & & \\
\hline $\mathrm{V} \times$ Fertilizer price & & - & + & & - & & + & - & + & & - & & & & & & & \\
\hline $\mathrm{V} \times$ Land price & & & - & & & & - & & - & & & & - & & - & & & \\
\hline $\mathrm{V} \times$ Rice price & & + & & - & & & - & + & & - & & + & & - & + & & - & + \\
\hline $\mathrm{V} \times \mathrm{c} \_\mathrm{n} \_$eff_10_y & & & & & & & & & & & & & & + & & + & & + \\
\hline $\mathrm{V} \times \mathrm{c} \_\mathrm{n} \_$eff 10 yc & & & & & & & & & & & & & - & - & & & & \\
\hline $\mathrm{V} \times \mathrm{c}$ n_emp_eff 5 & & + & + & + & - & + & & + & + & + & - & & - & + & + & & & \\
\hline $\mathrm{V} \times$ Health & - & + & & + & & & & + & & & & & & + & & - & + & + \\
\hline $\mathrm{V} \times$ Relief program & & & & & & & - & & & - & & & - & & & - & - & - \\
\hline $\mathrm{V} \times$ No land certificate & & - & & & - & & & - & & & - & & + & & + & - & + & \\
\hline $\mathrm{V} \times$ Land spending & - & & - & & + & - & & & & + & + & & & + & & - & & \\
\hline Rainfall (current) & - & & & - & + & & - & & & - & + & + & - & + & - & & & \\
\hline Temperature (current) & & & + & + & & & & & + & & & & - & & & - & & \\
\hline Disaster & & & - & - & & - & & & - & & & & + & - & - & & & \\
\hline Male $>60$ & & & + & + & & & & & + & + & & & & - & & & + & \\
\hline Male $20-60$ & & & + & + & & + & + & & + & + & & + & & & & - & - & - \\
\hline Male 6-19 & & & & + & + & & & & & + & + & & + & & & & - & \\
\hline Male $0-5$ & & - & & + & & & & - & & & & & + & + & & - & & \\
\hline Female $>60$ & & + & + & + & & + & & + & & & & & + & & - & & + & \\
\hline
\end{tabular}




\begin{tabular}{|c|c|c|c|c|c|c|c|c|c|c|c|c|c|c|c|c|c|c|}
\hline \multirow[b]{4}{*}{ Dependent variables } & \multicolumn{18}{|c|}{$\begin{array}{l}\text { Sector of household income earning activities for which EOS, and effect of market } \\
\text { participation is estimated }\end{array}$} \\
\hline & \multicolumn{6}{|c|}{$\begin{array}{l}\text { Agriculture vs. all non- } \\
\text { agricultural activities }\end{array}$} & \multicolumn{6}{|c|}{$\begin{array}{l}\text { Agriculture vs. non- } \\
\text { agricultural enterprises of } \\
\text { the household }\end{array}$} & \multicolumn{6}{|c|}{ Within agriculture } \\
\hline & \multicolumn{3}{|c|}{$\begin{array}{c}\text { Intensive } \\
\text { market } \\
\text { participants } \\
\end{array}$} & \multicolumn{3}{|c|}{$\begin{array}{l}\text { Subsistence } \\
\text { households }\end{array}$} & \multicolumn{3}{|c|}{$\begin{array}{c}\text { Intensive } \\
\text { market } \\
\text { participants }\end{array}$} & \multicolumn{3}{|c|}{$\begin{array}{l}\text { Subsistence } \\
\text { households }\end{array}$} & \multicolumn{3}{|c|}{$\begin{array}{c}\text { Intensive } \\
\text { market } \\
\text { participants }\end{array}$} & \multicolumn{3}{|c|}{$\begin{array}{l}\text { Subsistence } \\
\text { households }\end{array}$} \\
\hline & $\mathbf{A}$ & B & $\mathbf{C}$ & $\mathbf{A}$ & B & $\mathbf{C}$ & $\mathbf{A}$ & B & $\mathbf{C}$ & $\mathbf{A}$ & $\mathbf{B}$ & $\mathbf{C}$ & $\mathbf{A}$ & B & $\mathbf{C}$ & $\mathbf{A}$ & $\mathbf{B}$ & $\mathbf{C}$ \\
\hline Female $20-60$ & & + & & + & - & + & & + & + & & - & & - & & + & + & + & \\
\hline Female $6-19$ & & & & & & & & & & - & & - & - & & & + & & \\
\hline Female $0-5$ & - & - & & - & + & & & - & & & + & & & & & & & \\
\hline Female head & & - & & & & - & & - & + & + & & & - & & + & & & \\
\hline Education of head & & & & & - & & & & & & - & & & + & + & + & + & \\
\hline Education of WAM & & & & + & + & & & & - & & + & - & & & - & & - & \\
\hline Road & & - & & - & - & & & - & & & - & & & + & & + & & \\
\hline Market & & + & - & & + & - & & + & & & + & & + & - & + & - & - & \\
\hline Post Office & - & & & + & & & & & & & & & & + & & & & - \\
\hline Bank & & - & & - & & + & & - & & & & + & & - & - & & - & \\
\hline Radio station & + & - & - & & & & & - & & & & & & - & - & & & \\
\hline Internet & & - & & & & + & & - & - & & & & + & & & & & \\
\hline Asset & & & & + & & & & & & + & & + & & & & - & & \\
\hline Fridge & & & & & & & + & & & & & & - & & - & + & & \\
\hline Cooking & & & + & - & & & & & & & & & & & & & & \\
\hline Mobile phone & - & & - & - & & & & & & - & & & - & - & & & & \\
\hline Extension & & - & - & & & - & & - & - & & & & - & - & - & & + & \\
\hline Wage (male) & & + & & + & & & & + & & + & & & - & & - & & & \\
\hline Wage (female) & + & + & & + & & & + & + & + & & & & & & + & & & \\
\hline Fertilizer price & & + & & & + & & - & + & & & + & & & & + & & & \\
\hline Land price & & & + & & & & + & & + & & & & + & & + & & & \\
\hline Rice price & & - & & + & & & + & - & & + & & & & + & - & & + & - \\
\hline c_n_eff $10 \mathrm{y}$ & & & & & & & & & & & & & & - & & - & & - \\
\hline c_n_eff_10 yc & & & & & & & & & - & & & & + & + & & & & \\
\hline c_n_emp_eff_5 & & - & - & - & + & - & & - & - & - & + & & + & - & - & & & \\
\hline Health & + & - & & - & & & & - & & & & & & - & & + & - & - \\
\hline Relief program & & & & & & & + & & & + & & & + & & & + & + & \\
\hline Land certificate & & + & & & + & & & + & & & + & & - & & - & + & - & \\
\hline Land spending & + & & + & & - & + & & & & - & - & & & - & & + & & \\
\hline & & & & & & & & & & & & & & & & & & \\
\hline $\begin{array}{l}\text { Year dummy * province } \\
\text { dummy }\end{array}$ & & & & & & & & & Incl & Ided & & & & & & & & \\
\hline Household fixed effects & & & & & & & & & Incl & ided & & & & & & & & \\
\hline Intercept & & & & & & & & & Incl & ided & & & & & & & & \\
\hline Sample size & & & & & & & & & & & & & & & & & & \\
\hline
\end{tabular}

Source: Authors.

"Intensive market participants" = households with market participation indicators above sample median; "Subsistence households" = = households with market participation indicators below sample median

Dependent variables: A = Production cost of output $; ; \quad B=$ Production cost of output $1 ; \quad \mathrm{C}=$ Joint production costs of outputs 1 and 2

Variable notations: Output 1 = agriculture, Output 2 = non-agricultural income earning activities; For EOS within agriculture, Output 1 = rice; Output 2 = non-rice agricultural commodities.

$\mathrm{V}=$ production values of respective activities; WAM = working-age members; c_n_eff_10_y = whether there is firms/factories/enterprises in the community; c_n_eff_10_yc $=$ whether there is firms/ factories /enterprises in the community that employs workers from this community; c_n_emp_eff_5 = Number of workers employed in the 5 largest non-farm firms/ factories / enterprises in the community 


\section{ALL IFPRI DISCUSSION PAPERS}

All discussion papers are available here

They can be downloaded free of charge

INTERNATIONAL FOOD POLICY RESEARCH INSTITUTE

www.ifpri.org

\section{IFPRI HEADQUARTERS}

1201 Eye Street, NW

Washington, DC 20005 USA

Tel.: +1-202-862-5600

Fax: +1-202-862-5606

Email: ifpri@cgiar.org

SOUTH ASIA REGIONAL OFFICE

Block C, NASC Complex, DPS Marg

Opposite Todapur, Pusa

New Delhi 110012 India

Phone: +91-11-66166565

Fax: +91-11-66781699

Email: ifpri-newdelhi@cgiar.org

https://southasia.ifpri.info/ 